\title{
Evolutionary History of Terrestrial Pathogens and Endoparasites as Revealed in Fossils and Subfossils
}

\author{
George Poinar Jr. \\ Department of Integrated Biology, Oregon State University, Corvallis, OR 97331, USA \\ Correspondence should be addressed to George Poinar Jr.; poinarg@science.oregonstate.edu
}

Received 9 February 2014; Revised 29 April 2014; Accepted 2 May 2014; Published 12 June 2014

Academic Editor: Renfu Shao

Copyright (C) 2014 George Poinar Jr. This is an open access article distributed under the Creative Commons Attribution License, which permits unrestricted use, distribution, and reproduction in any medium, provided the original work is properly cited.

The present work uses fossils and subfossils to decipher the origin and evolution of terrestrial pathogens and endoparasites. Fossils, as interpreted by morphology or specific features of their hosts, furnish minimum dates for the origin of infectious agents, coevolution with hosts, and geographical locations. Subfossils, those that can be $\mathrm{C}^{14}$ dated (roughly under 50,000 years) and are identified by morphology as well as molecular and immunological techniques, provide time periods when humans became infected with various diseases. The pathogen groups surveyed include viruses, bacteria, protozoa, fungi, and select multicellular endoparasites including nematodes, trematodes, cestodes, and insect parasitoids in the terrestrial environment.

\section{Introduction}

The world is filled with pathogens that have been around for millions of years, yet we know very little about their origins and evolution. The present work uses fossils and subfossils to decipher the origin and evolution of terrestrial pathogens and endoparasites. Fossils furnish minimum dates for the origin of infectious agents, coevolution with hosts, and geographical locations. Subfossil remains, those that can be $\mathrm{C}^{14}$ dated (roughly under 50,000 years), provide time periods when humans became infected with various diseases. The detection of fossil infectious agents is based on morphology or specific features of their hosts while molecular and immunological techniques can be used as well in searching for subfossil pathogens and parasites.

Arthropods in amber that were vectoring vertebrate pathogens have provided unique information on the origin and evolution of human and animal diseases [1]. Such detailed preservation is due to the instant death of the vector, its rapid desiccation, and impregnation by natural fixatives. Dates for the various amber sites mentioned in the present work are Dominican, $20-15$ mya based on foraminifera and 45-30 mya based on coccoliths; Mexican, 22-26 mya; Baltic, 40-50 mya; Myanmar (Burmese), 97-110 mya; and Lebanese, $130-135$ mya.
The pathogen groups surveyed include viruses, bacteria, protozoa, and fungi in the terrestrial environment. Also included are multicellular endoparasites such as nematodes, trematodes, cestodes, and select insect parasitoids. Examples are included when both the pathogen/parasite and host occur together as determined by morphological, molecular, or immunological evidence. Reports of disease in the fossil record based on host signs have been summarized previously [2-4].

\section{Pathogens}

2.1. Viruses. Viruses are probably quite ancient and may have existed some 4 billion years ago with bacteria as hosts. The nearly 2000 species of viruses infecting plants and animals today are probably a conservative estimate of their diversity [5]. All estimates on the evolutionary history of viruses are based on molecular analyses since fossils of such small, fragile structures are almost nonexistent. Evidence of some viruses has been found in subfossil remains based on DNA analysis [4] but the only fossil evidence of infectious diseases caused by viruses associated with their hosts is insect polyhedrosis, polynida, and iridoviruses. The polyhedra of nuclear polyhedrosis viruses (Baculoviridae) and cytoplasmic polyhedrosis 


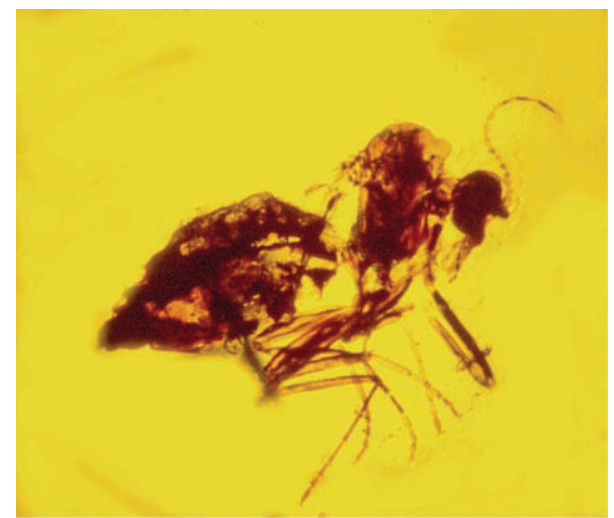

FIgURE 1: Early Cretaceous Myanmar amber biting midge (Protoculicoides sp.; Diptera: Ceratopogonidae) that contains polyhedra of a cytoplasmic polyhedrosis virus in its midgut cells.

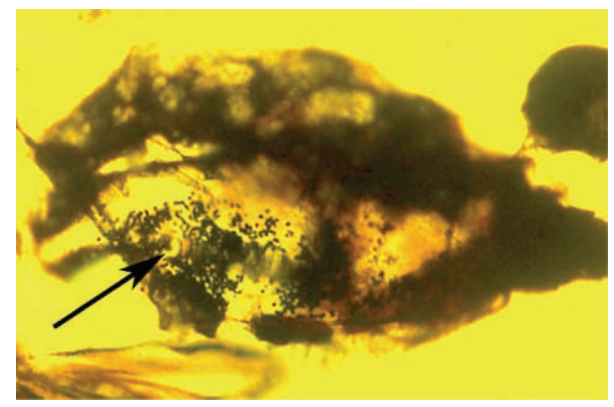

FIGURE 2: Group of polyhedra (arrow) of a cytoplasmic polyhedrosis virus in the midgut cells of the Early Cretaceous biting midge in Figure 1.

viruses (Reoviridae) are just large enough to be detected with the light microscope. Based on the size of the polyhedra, the particular organs in which they occur, and the type of insect hosts, it was possible to identify a cytoplasmic polyhedrosis virus infecting a biting midge (Figures 1, 2, and 3) and a nuclear polyhedrosis virus infection in a sand fly (Figures 4 and 5), both in Early Cretaceous amber from Myanmar [6]. These records provide a minimum date for the origin of the Baculoviridae and Reoviridae and suggest that some human arboviruses could have evolved first as pathogens of bloodsucking flies.

A specialized group of viruses that are carried by parasitic wasps of the families Braconidae and Ichneumonidae are the Polydnaviridae. Genomes of polydnaviruses are integrated into the wasp genome and virus replication occurs in the reproductive system of the female wasp. During oviposition, the virus is introduced along with the wasp eggs into the body of potential hosts. The virus replicates in the host and affects the host immune system by preventing it from encapsulating and destroying the wasp eggs. The transfer of these virus particles from wasp to host was first observed in 1975 with the ichneumonid, Casinaria infesta, and its plutellid moth host [7] and in 1976 with the braconid Phanerotoma flavitestacea and its pyralid moth host, Paramyelois transitella [8]. Since that time, the field has expanded and the polydnaviruses are

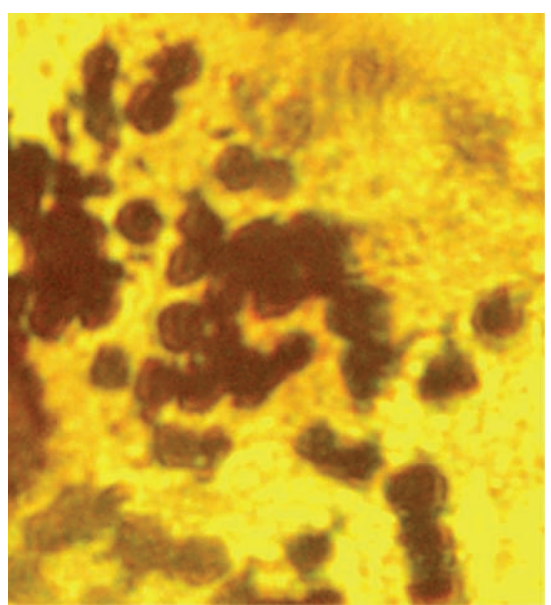

FIGURE 3: Detail of polyhedra of a cytoplasmic polyhedrosis virus in the midgut cells of an Early Cretaceous biting midge in Figure 1.

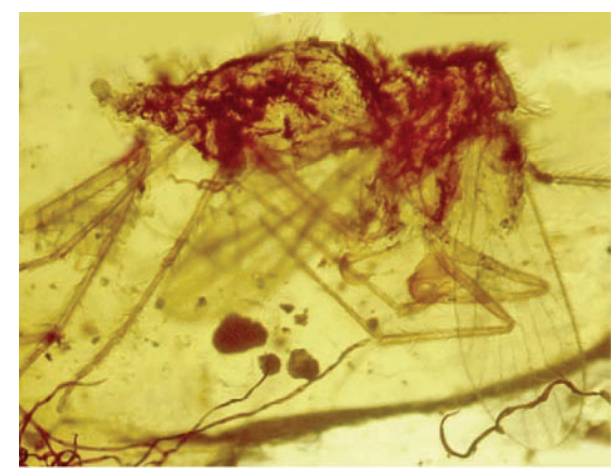

Figure 4: An Early Cretaceous Myanmar amber sand fly (Diptera: Psychodidae) infected with a nuclear polyhidrosis virus.

now included in the new discipline of Paleovirology, which infers viral evolution from host genome sequence data $[9,10]$.

Presently the family Polydnaviridae contains two genera. The genus Bracovirus occurs in the calyx cells and fluid of the female wasps of the family Braconidae and the genus Ichnovirus is associated with female wasps of the family Ichneumonidae. Because of the close association between the virus and members of these two families, one can assume that these viruses existed in ancient wasps of these lineages, such as the fossil braconid and ichneumonid wasps depicted in Dominican amber (Figures 6 and 7) and even in the primitive braconid wasp in 100 million year old amber from Myanmar (Figure 8).

A group of invertebrate pathogenic viruses whose presence often can be determined by color changes of the host are the iridoviruses. These double-stranded DNA viruses are icosahedral and hexagonal in cross section. The isopod iridescent virus infects terrestrial pillbugs and sowbugs and in the later stages of infection turns normal brown hosts to various shades of violet, blue, and purple [11]. In fact, an isopod thus colored can be assured of having an iridoviral infection. The bluish color is the result of paracrystalline arrays of viral particles (virions) filling the epidermal and 


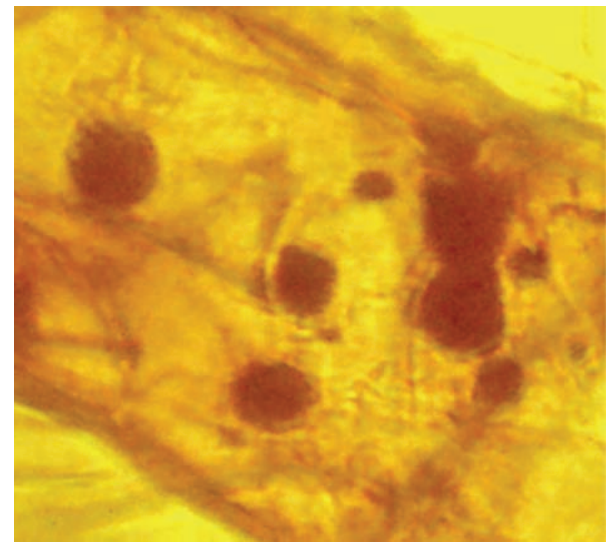

FIGURE 5: Detail of polyhedra of a nuclear polyhedrosis virus in the Early Cretaceous sand fly in Figure 4.

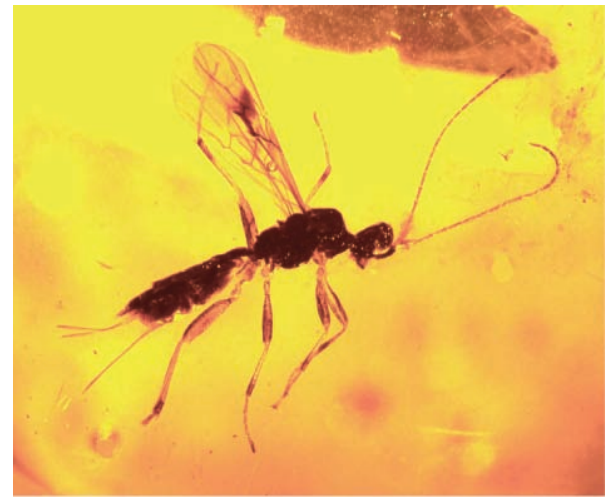

Figure 6: A female braconid wasp (Hymenoptera: Braconidae) in Dominican amber that is probably carrying the genome of a Bracovirus in its reproductive system.

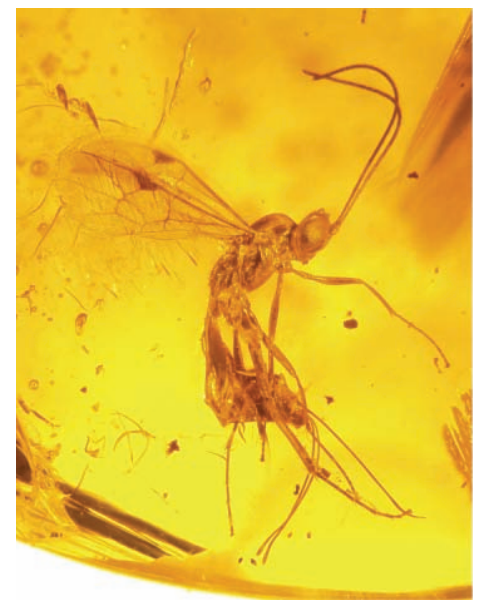

Figure 7: A female ichneumonid wasp (Hymenoptera: Ichneumonidae) in Dominican amber that is probably carrying the genome of an Ichnovirus in its reproductive system.

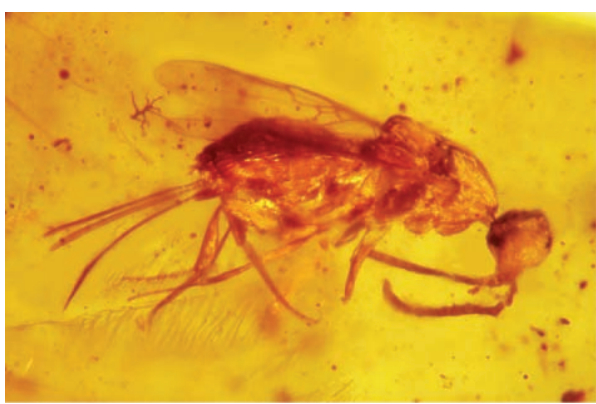

FIgURE 8: A primitive braconid wasp (Hymenoptera: Braconidae) in Early Cretaceous Myanmar amber that could be carrying the genome of a polydnavirus in its reproductive system.

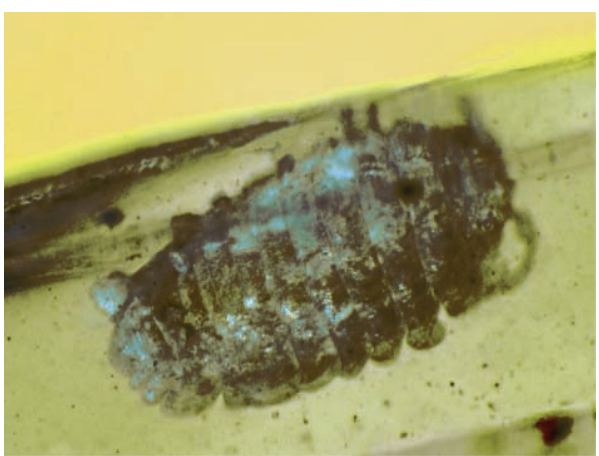

FIgURE 9: A bluish tinted terrestrial isopod in Early Cretaceous Myanmar amber that could be infected with the isopod iridescent virus.

other cells of the isopod that is eventually killed by the infection. An isopod in Cretaceous amber from Myanmar that has iridescent blue areas on its body is assumed to be infected with an ancient strain of the isopod iridescent virus (Figure 9). This is another example of identifying fossil viruses using indirect, but reliable evidence derived from our present knowledge.

2.2. Bacteria. Bacteria are ubiquitous and there are numerous reports of fossil associations between putative bacteria and various animals and plants $[2,3]$. However, most of these reports refer to signs indicating a possible bacterial infection and actual bacteria are absent. One example is the dark areas on the body of the Burgess Shale onychophoran, Aysheaia pedunculata, that are thought to represent bacterial infections [12]. Other examples of indirect presence of bacteria are fossil fish with luminescent organs similar to those on their present day descendants that are operated by luminescent bacteria [3] or insects producing flatus in fossilized resin [13].

Filamentous cells occurring in the marine environment some 3.6 billion years ago represent some of the earliest known bacteria [14]. When terrestrial bacterial first appeared and formed associations with animals and plants is unknown since fossil bacteria are quite difficult to detect. Their small size and delicate structure (except for spores) are not prone to fossilization. Evidence of the early evolution of some specific 


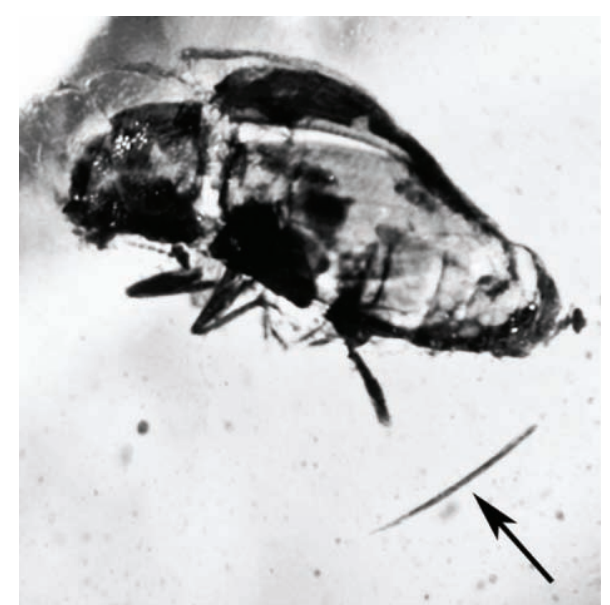

Figure 10: An Early Cretaceous Myanmar amber entomopathogenic nematode, Proheterorhabditis burmanicus (arrow), adjacent to its beetle host.

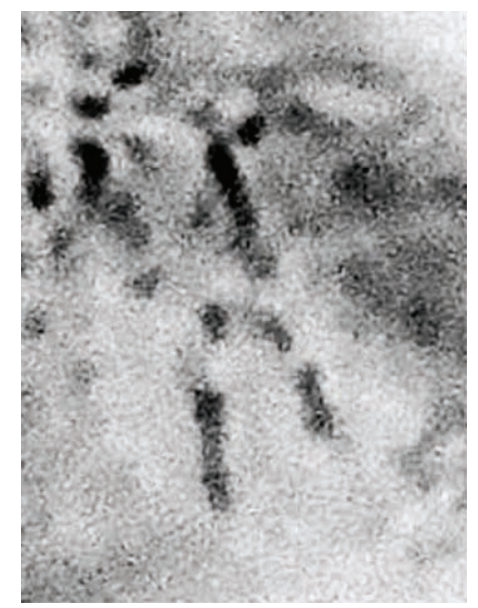

FIgURE 11: Bacterial cells of Photorhabdus inside the Early Cretaceous Myanmar amber beetle shown in Figure 10.

lineages of pathogenic bacteria has appeared in fossilized resin.

The oldest known definite fossil disease-producing bacteria are associated with an entomopathogenic nematode of the Heterorhabditis clade in Early Cretaceous amber [15]. Several infective stages of the insect pathogenic nematode, Proheterorhabditis burmanicus, were preserved as they emerged from their beetle host in Myanmar amber (Figure 10). Extant members of the Heterorhabditis clade carry and release spores of the luminescent bacterium, Photorhabdus luminescens, into the body cavity of insects. The bacteria multiply and kill the insects within 24 hours. The nematodes feed on the combined bacteria host breakdown tissues and the newly formed infective stage juveniles carry these bacterial cells into a new host. Bacterial cells in the fossil beetle (Figure 11) adjacent to the nematode resembled those of extant Photorhabdus spp. and are presumed to have been introduced into the beetle by Proheterorhabditis burmanicus.

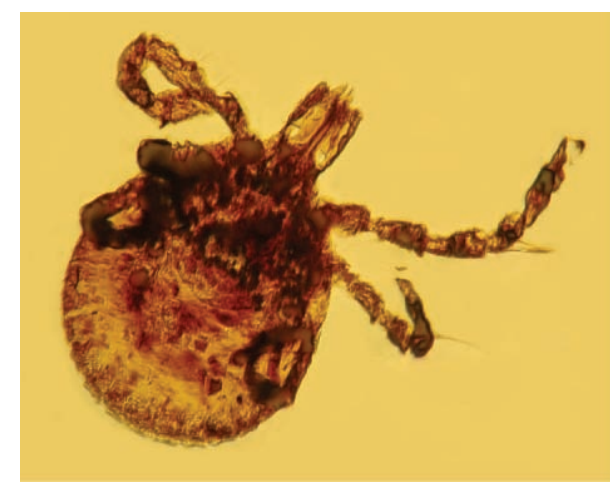

Figure 12: Larval Ambylomma hard tick in Dominican amber.

Ticks (Figure 12) carry a number of bacterial pathogens. One of special interest is the spirochete, Borrelia burgdorferi, the causal agent of Lyme disease. An ancient spirochete with characters of Borrelia was found in the midgut and hemocoel of a larval hard tick belonging to the genus Amblyomma (Arachnida: Ixodidae) in Dominican amber (Figures 13 and 14) [16]. The presence of spirochetes in the hemocoel indicated that the tick was a competent vector since spirochetes do not enter the hemocoel of incompetent vectors [17]. Vertebrate hosts of extant Amblyomma ticks are reptiles, birds, and mammals and remains of all three of these groups occur in Dominican amber [18]. This discovery shows how ancient some lineages of tick-vectored pathogens can be. It is likely that genetic material of this fossil spirochete contributed to the genome of extant Borrelia lineages, including those species that infect humans. The earliest record of Lyme disease was recently reported from the Tyrolean Iceman, a 5,300-year-old mummy discovered in 1991 in the Italian Alps. During a genomic analysis of the Iceman, sequences corresponding to $\sim 60 \%$ of the genome of Borrelia burgdorferi indicated that the Iceman suffered from Lyme borreliosis [19].

The fossil record of hard ticks extends back to the Early Cretaceous $[20,21]$. This sets a time period when these arachnids could have acquired spirochetes, followed by a period of coevolution that established the vertebrate cycle and increased vector competency. The origin of Borreliosis is a mystery. It is likely that Borrelia began as a free-living spirochete that could have made contact with tick eggs deposited in the soil. However, so little is known about interactions of Borrelia sp. with present day ticks that this scenario is difficult to prove. Yet if Borrelia began as a tick parasite, it could have been passed from mother to offspring by vertical or transovarial transmission (TOT). The spirochetes may have initially served as symbiotes, since TOT is normally how symbiotic microorganisms are passed in hosts. A later evolutionary step would be entering the salivary glands where they could be transferred to vertebrates.

An example of this evolutionary scenario is the establishment and transfer of rickettsial organisms in arthropods [22]. Rickettsias occur in many locations inside the alimentary tract and body tissues of a wide range of animals [23, 24]. Some symbiotic species, like Wolbachia, are beneficial and assist in the digestion of blood meals, while other rickettsias 


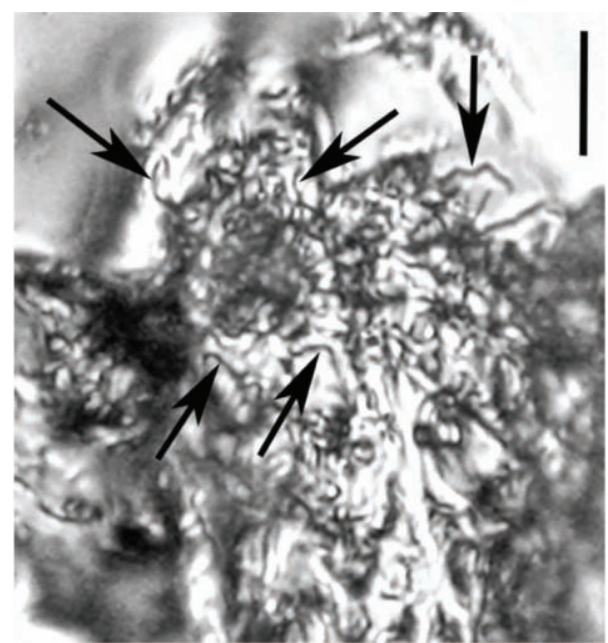

FIGURE 13: Spirochetes (arrows) within the chelicerial sheath and surrounding the hypostome of a larval Ambylomma tick in Dominican amber similar to the one shown in Figure 12. Scale bar $=16 \mu \mathrm{m}$.

are pathogenic to both arthropod vectors and their vertebrate hosts. Finding evidence of rickettsias in the fossil record is difficult but a recent study showed various stages of a rickettsial organism in the Early Cretaceous Myanmar amber hard tick, Cornupalpatum burmanicum (Figure 15). The rickettsial cells occurred in the remains of gastric ceca (Figure 16). Cocci, diplococci, and short, rod shaped cells borne singly or in short chains were dividing by binary fission. The rods ranged from 0.4 to $0.8 \mu \mathrm{m}$ in width by $1.3-1.7 \mu \mathrm{m}$ in length. In some areas, ovoid cells surrounded by an apparent mucoprotein, slime layer (haloes), were present. Such "halo" cells are known to occur in rickettsial populations and are considered to represent infective stages of the disease process [22, 23]. Since the cells were developing in the gastric cecal cells, the fossil could be related to any one of the many species in the families of Rickettsiaceae or Anaplasmataceae [17, 23]. Ticks are known to vector a range of rickettsial pathogens, including Q-fever, tick typhus, and Boutonneuse fever, some of which cause diseases in reptiles [24], which makes dinosaurs possible hosts [25].

Insects relying solely on blood meals throughout their entire development often harbor symbiotic microorganisms [26]. While they can be considered parasites since they develop on a combination of the blood meal and digestive secretions from the insect, they may supply essential elements to their host, since blood is considered a nutritionally inadequate diet deficient in B vitamins. Nocardiform bacteria such as Rhodococcus assimilate proteins and carbohydrates in the lumen of the alimentary tract of blood-sucking triatomine bugs [27]. Species of this genus occur in soil and water as well as in the lumen of insect alimentary tracts. Past evidence of this clade was discovered when cells of Paleorhodococcus dominicanus were found in a fecal droplet adjacent to the triatome bug, Triatoma dominicana, in Dominican amber $[28,29]$. The fossil species consisted of numerous coccoid elements with associated mycelial fragments [29] (Figure 18).

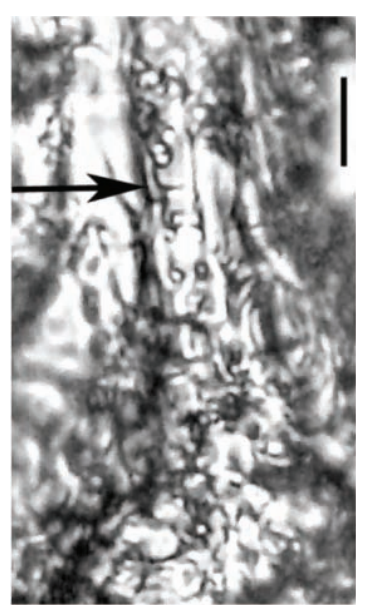

Figure 14: Spirochetes in the pharynx (arrow) of a larval Ambylomma tick in Dominican amber similar to the one shown in Figure 12. Scale bar $=13 \mu \mathrm{m}$.

While $P$. dominicanus could have been beneficial if it was assisting in the breakdown of blood components, it could also have been infectious since some species of Rhodococcus are pathogens, such as $R$. equi that infects horses.

A Bacillus sporangium inside of the body of the mycetophagous nematode, Oligaphelenchoides atrebora in Mexican amber (Figure 19), could indicate the presence of an infectious disease in the entire nematode population [30]. Bacillus sp. are known to infect extant nematodes [31] as well as insects and humans. However, fossil evidence of such infections is rare, even though the ancient presence of $B$. sphaericus, $B$. subtilis, and $B$. circulans was found in amber, sedimentary rocks, and salt deposits [32].

One of the most studied bacterial diseases is the plague, which has killed countless humans throughout history. Plague is caused by a small, pleomorphic bacterium known as Yersinia pestis that is transmitted by fleas. This pathogenic strain probably evolved from one of the free-living species of Yersinia that occur in soil, fresh water, foods, fish, and various animals [33]. The chances of finding fossil cells of $Y$. pestis are extremely slim. Some bacterial cells attached to the proboscis of a fossil Rhopalopsyllus flea in Dominican amber (Figure 20) have the morphological features of Yersinia (Figure 21) although it is not possible to confirm their identity. However, the extant Rhopalopsyllus cavicola is one of 125 species of fleas capable of transmitting $Y$. pestis, in this case to cavy rodents in the American tropics $[34,35]$.

Sophisticated molecular and immunological methods can now be used not only to identify pathogens, but to compare various strains that appeared throughout history. One of the best sources of ancient DNA for such studies is roots and crowns of teeth from the victims of various epidemics (Figure 22). These were used to characterize strains of $Y$. pestis that were responsible for the Black Death that struck Europe in the 14th to 17th centuries [36]. 


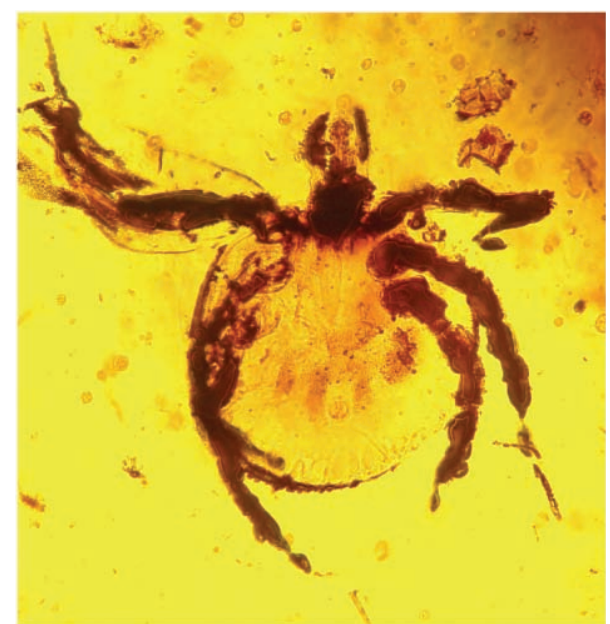

FIgURE 15: Early Cretaceous Myanmar amber larval hard tick, Cornupalpatum burmanicum that contains rickettsial organisms.

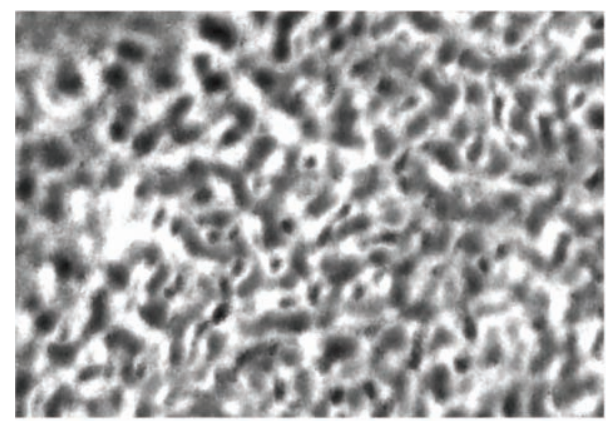

FIGURE 16: Short rods and cocci of a rickettsial organism in a gastric ceca of the Early Cretaceous larval hard tick shown in Figure 15.

Past cholera epidemics also resulted in high mortality rates (Figure 23). Using a preserved intestinal portion from a victim of the 1849 cholera outbreak in Philadelphia, molecular techniques were used to reconstruct the genome of the causative organism, Vibrio cholerae [37].

Teeth are also a good source of decay-causing bacteria. One report characterizes filamentous actinomycetes in a tooth from an Eocene rabbit in Montana [38], thus documenting the earliest record of tooth infection in placental mammals.

2.3. Protozoa. Protozoa, with some 120,000 described species, are an ancient group with a fossil record extending back to the Archean Eon, some 2 billion years ago. Protozoa probably originated in the sea and soon afterwards formed symbiotic associations with terrestrial life forms. Eventually, they entered the lumen of the alimentary tract of invertebrates and developed on partially digested food. Some of these became permanent residents in the guts of various insects such as termites, where the protozoa served a mutualistic role of digesting cellulose. Other protozoans invaded the internal organs of their hosts and became parasites. During their evolution, some became

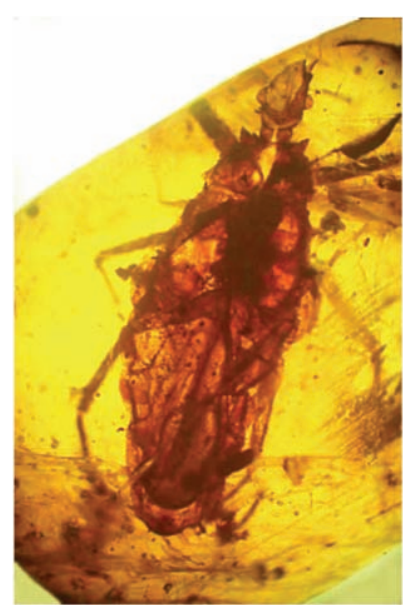

Figure 17: A Kissing bug, Triatoma dominicana, in Dominican amber with an actinobacteria infection.

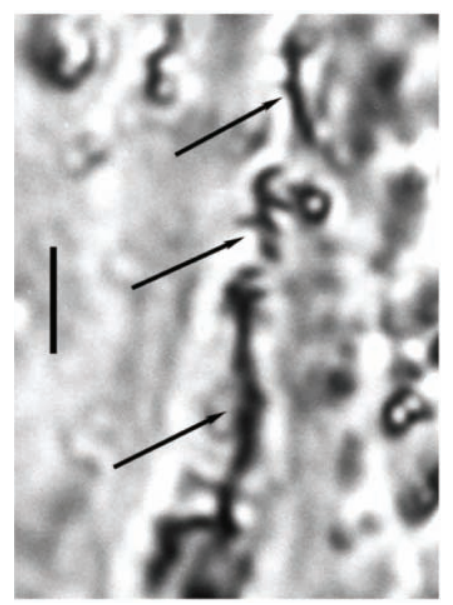

FIgURE 18: Filaments of the actinobacteria, Paleorhodococcus dominicanus (arrows) in an anal deposit of the Dominican amber Kissing bug shown in Figure 17. Bar $=7 \mu \mathrm{m}$.

closely associated with blood-sucking arthropods, which transported them into vertebrates where they became established as true parasites with the potential of causing disease. A few invaded the tissues of plants but the present diversity of plant parasitic protozoa is quite low.

Today a number of arthropods vector parasitic protozoa and early lineages of some of these became entrapped in amber, thus providing clues to the evolution of human diseases. Two basic types of development evolved between arthropod vectors and their protozoan parasites. The first is where the protozoans only develop in the gut lumen of the vector. Examples are members of the trypanosome lineage that include Leishmania vectored by sand flies. The second is where the protozoans penetrate the gut wall and undergo development in the body cavity of the vector. Examples are the various malarial pathogens vectored by several arthropods, especially mosquitoes.

The first fossil protozoan pathogen to be discovered was one of the former types that were in the gut lumen 


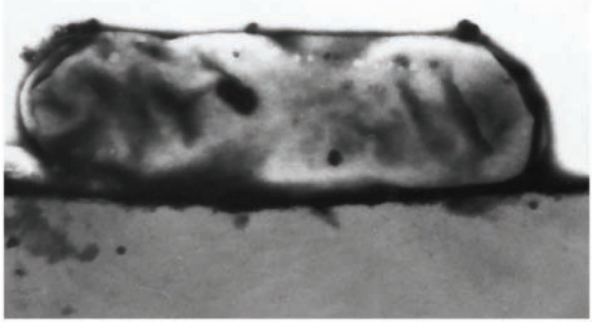

FIGURE 19: A Bacillus sporangium developing inside the body cavity of the mycetophagous nematode, Oligaphelenchoides atrebora, in Mexican amber.

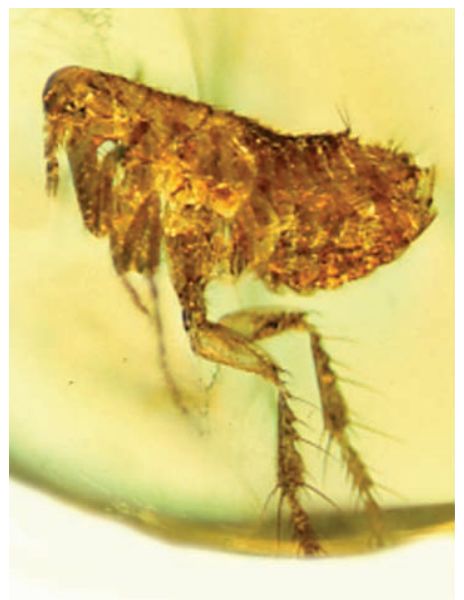

Figure 20: A flea (Rhopalopsyllus sp.) in Dominican amber.

of a phlebotomine sand fly entrapped in Early Cretaceous Myanmar amber (Figure 24) [39]. In the midgut lumen of the sand fly, Palaeomyia burmitis, were various stages of the leishmanial parasite, Paleoleishmania proterus [40] (Figure 25). Aside from normal promastigotes, elongate nectomonad promastigotes (Figure 26) and short procyclic promastigotes (Figure 27) were also present. Vertebrate infective amastigotes occurred in the proboscis of the fossil sand fly (Figure 28) and a view into the thoracic lumen of the fossil sand fly revealed nucleated vertebrate blood cells. Some of these cells contained developing amastigotes (Figure 29), obviously acquired during a recent blood meal. Based on morphological characteristics of the blood cells, the vertebrate host was considered to be a reptile and Paleoleishmania proterus was thought to be an ancestor of the genus Sauroleishmania that infects lizards and snakes today [41].

The life cycle of Paleoleishmania proterus was probably similar to that of leishmanial parasites vectored today by sand flies [42]. Amastigotes were acquired from the blood of a vertebrate during feeding. These developed into short ovoid procyclic forms that then formed elongate nectomonad stages in the lumen of the alimentary tract of the sand fly. Metacyclic (paramastigote) forms were transferred back into a vertebrate during blood-feeding.

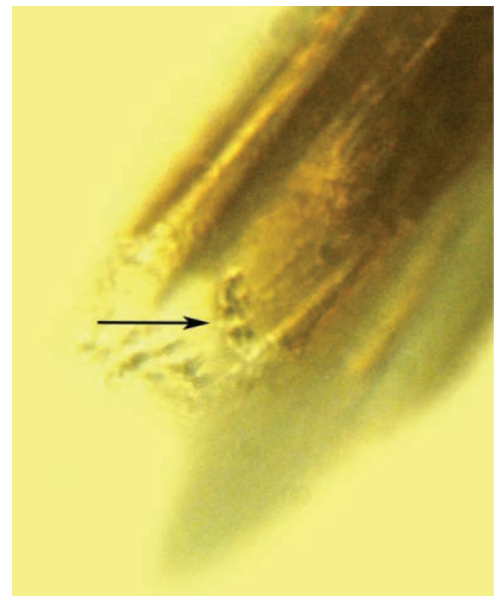

FIGURE 21: Bacterial cells (arrow) attached to the tip of the proboscis of the Dominican amber flea shown in Figure 20.

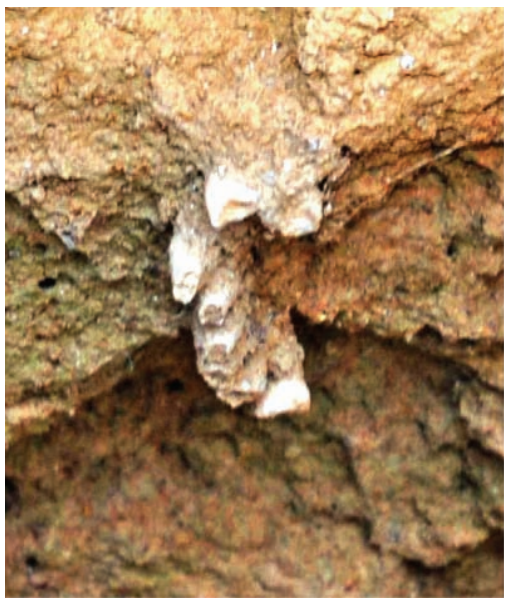

FIGURE 22: Human teeth from a victim of the plague discovered in a 16th century burial pit in Tuscany. Such teeth are the "treasure trove" for archaeologists wishing to obtain DNA from ancient remains (photo courtesy of Debi Poinar).

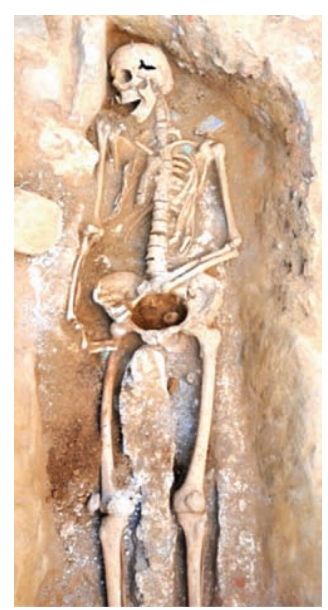

FIGURE 23: DNA analysis showed that this individual from a burial pit in Tuscany died from cholera around 1850 (photo courtesy of Debi Poinar). 


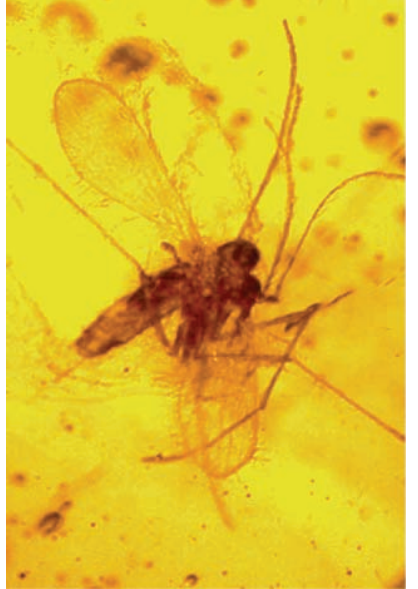

Figure 24: The Early Cretaceous Myanmar amber sand fly, Palaeomyia burmitis, with stages of the trypanosomatid, Paleolishmania proterus.

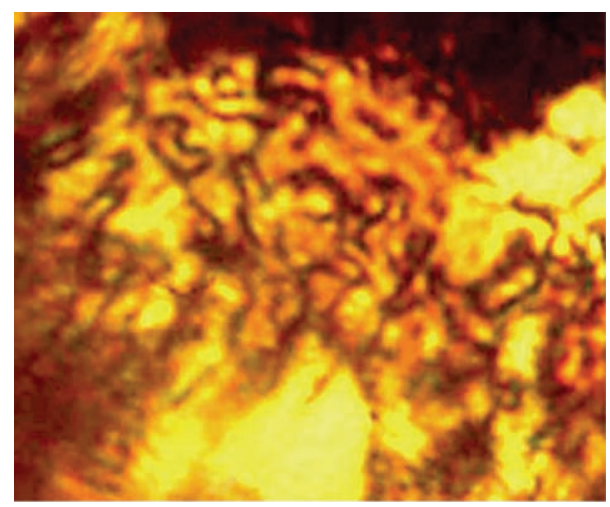

FIgURe 25: Promastigotes of the trypanosomatid, Paleolishmania proterus, developing in the midgut of the Early Cretaceous sand fly shown in Figure 24.

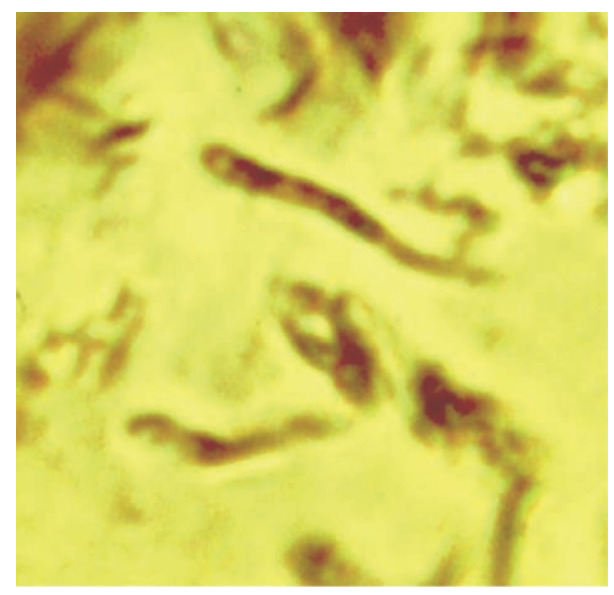

FIGURE 26: Elongate nectomonad promastigotes of Paleolishmania proterus developing in the midgut of the Early Cretaceous sand fly shown in Figure 24.

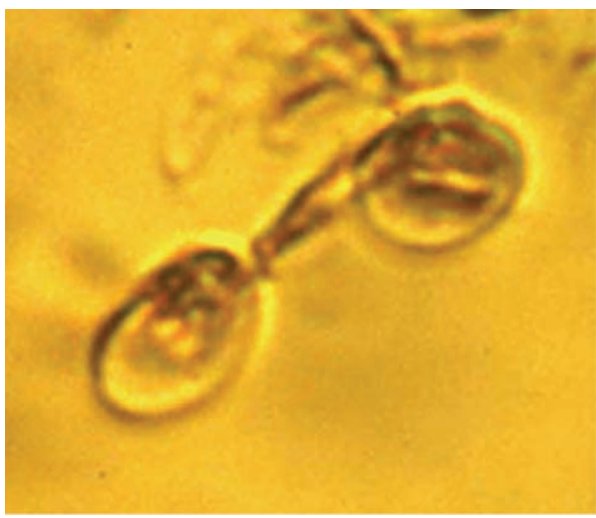

FIGURE 27: Short procyclic promastigotes of Paleolishmania proterus developing in the midgut of the Early Cretaceous sand fly shown in Figure 24 .

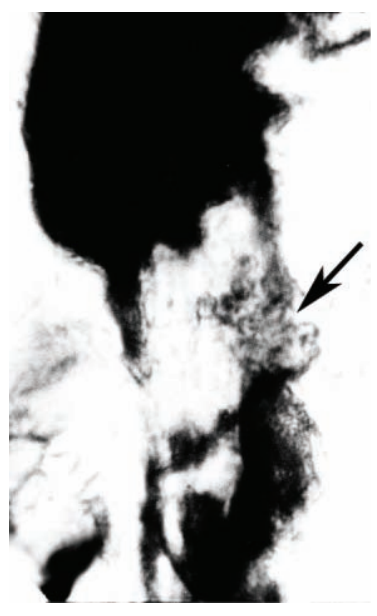

FIGURE 28: Amastigotes (arrow) of Paleolishmania proterus acquired from a vertebrate host in the proboscis of the Early Cretaceous sand fly shown in Figure 24.

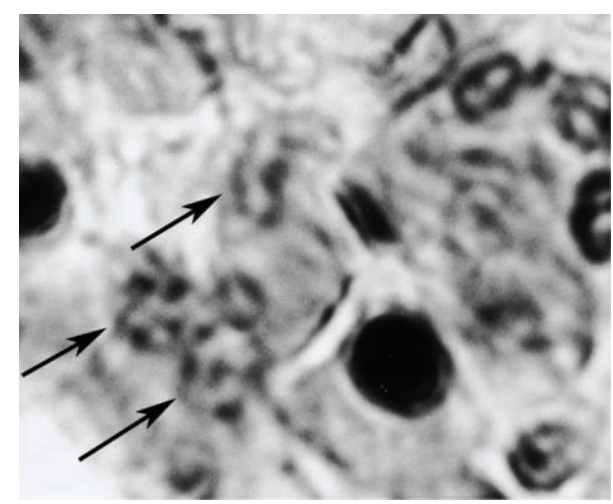

Figure 29: Amastigotes (small dark bodies [arrows]) of Paleolishmania proterus developing inside vertebrate blood cells in the thoracic lumen of the Early Cretaceous sand fly shown in Figure 24. 


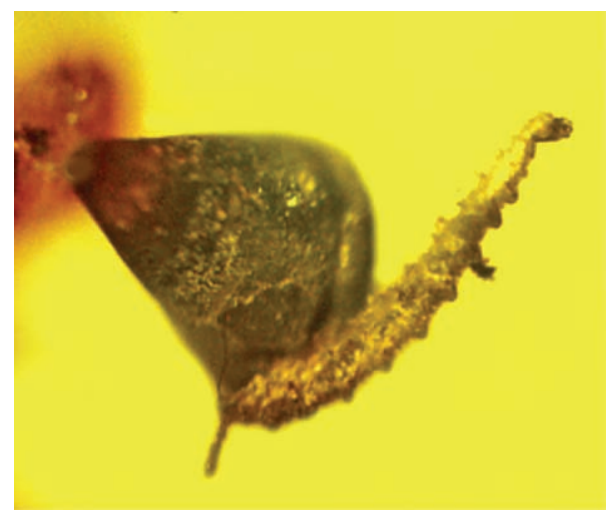

FIgure 30: One of two Early Cretaceous Myanmar amber sand fly larvae that contained flagellates inside the lumen of their alimentary tracts. Similar flagellates were associated with the adjacent club fungus.

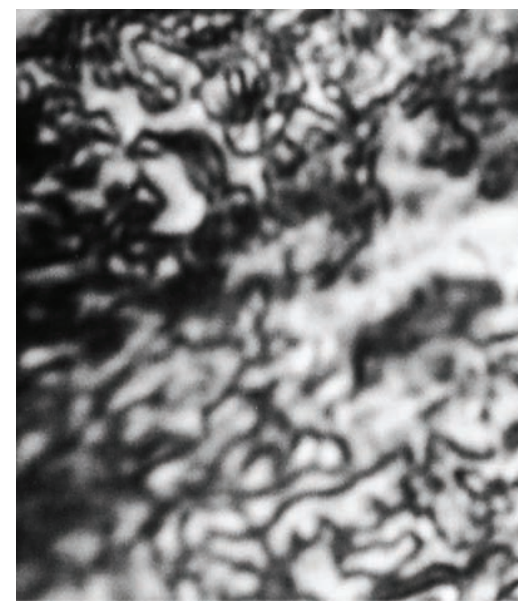

FIGURE 31: Flagellates inside the lumen of the alimentary tract of the Early Cretaceous sand fly larva shown in Figure 30.

How, when, and where protozoan vector associations originated are difficult to determine, especially when every association could have evolved slightly differently. Also past evidence of vector associations is extremely rare since most protozoans are too small and fragile to be recognized [43]. However, in some instances, clues to possible mechanisms exist. In the case of Leishmania and sand flies, the discovery of trypanosomes associated with sand fly larvae originating from the same Early Cretaceous Myanmar amber deposits provided a possible scenario for how these flagellates became established in sand flies. The two fossil sand fly larvae were adjacent to and probably feeding on a fruiting body of a coral mushroom, Palaeoclavaria burmitis (Figure 30) [44-46]. Associated with some expelled fecal material from both larvae were numerous flagellates. Similar flagellates surrounded the bases of the fungal fruiting bodies and were associated with debris attached to the cuticle of both sand flies. After polishing away a portion of the alimentary tract of one of the amber sand flies, numerous flagellates similar to those at the bases of the fungal fruiting bodies were also discovered in the lumen of its midgut (Figure 31).

Based on these findings, the following scenario for the acquisition of Leishmania by sand flies is presented. Freeliving trypanosomes developing in the same microhabitat as the sand fly larvae and club fungi were ingested by the larvae. They may have served as food at first, but eventually the trypanosomes began to multiply inside the gut of the sand fly and were carried transtadially from the larva through the pupa and into the adult. Once established in the gut of the adult sand fly, the flagellates were eventually transferred to vertebrates during blood feeding and a vector association was established. Molecular studies showing that insects were the first hosts of trypanosomatids [47] support the above scenario on the origin of parasitic Leishmania through larval acquisition of free-living trypanosomatids.

Flagellate-insect associations, some of which could evolve into vector relationships, occur today as shown by free-living trypanosomatids in the alimentary tract lumen of various insects. Species of the aquatic flagellate Crithidia can be found inside the gut lumen of mosquito larvae and Herpetomonas spp. occur in the larval habitats, as well as inside the gut lumen of fruit flies (Drosophilidae), scuttle flies (Phoridae), and muscid flies (Muscidae) [48]. Transtadial transmission of Crithidia fasciculata was experimentally achieved in the mosquito, Culiseta incidens [49]. Not only protozoa but also bacteria are known to be transmitted transtadially from larvae into adult Phlebotomus duboscqi [50]. The trypanosomatid, Leptomonas ctenocephali, is carried through the pupal stage into the adult dog flea, Ctenocephalides canis, and when mealworm larvae were experimentally infected with Leptomonas pyrrhocoris, they carried the flagellates though the pupal and into the adult stage [51].

The scenario of insect larvae acquiring free-living flagellates that are eventually carried into the adult stage may be how many insect vectors originally acquired pathogenic microorganisms. When such microbes were first transmitted into vertebrates, they would have had to deal with immune responses, which was probably achieved by entering specific tissues like the liver or blood cells. How many attempts it took before free-living trypanosomatids were established in sand flies and a vector relationship was established will never be known. However, it is obvious that a combination of confluent events resulted in successful host-vector associations.

So when did sand flies began to transmit Leishmania? A minimum date of 100 million years can be established from actual fossils in Early Cretaceous Myanmar amber. However, the fossil record of sand flies extends back to 125 million year Early Cretaceous Lebanese amber [52], although some suspect that sand flies existed in the Jurassic [53] or even in the Triassic [54].

As pathogens coevolve with their vectors, it is only natural that they would coevolve with their vertebrate hosts. Thus, successful establishment of Leishmania in mammals may have been predisposed by first infecting reptiles, especially since Paleoleishmania proterus infected reptiles in the Early Cretaceous [41]. Reptiles were probably the original hosts of Leishmania $[55,56]$. This scenario is supported by molecular 


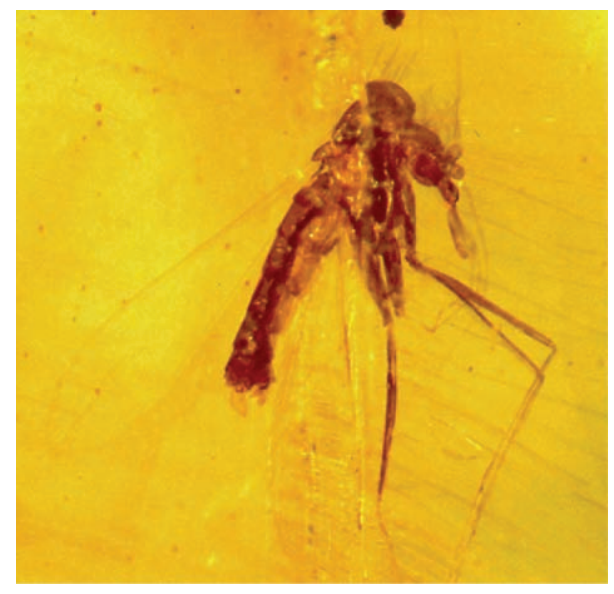

FIGURE 32: Lutzomyia adiketis, the Dominican amber sand fly vector of Paleoleishmania neotropicum.

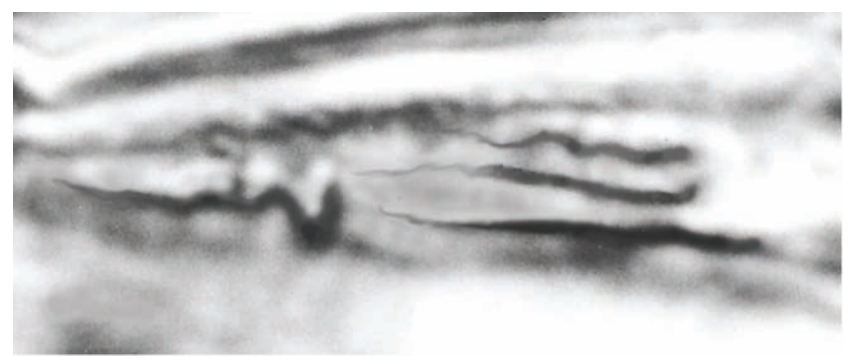

FIGURE 33: Four promastigotes of Paleoleishmania neotropicum in the proboscis of the Dominican amber sand fly shown in Figure 32.

data [57] and numerous reptilian trypanosome infections transmitted by sand flies today [58-61].

Did several foci of sand fly-Leishmania evolve over time in different geographical areas or was this vector association a single event? Two theories supporting the latter scenario were proposed on the place of origin of Leishmania. One proposes a Palearctic origin with reptiles as the first vertebrate hosts. The pathogen was later carried across Beringia into the Nearctic and then into the Neotropical region via the Panamanian land bridge [62]. The second theory placed the origin of Leishmania in the Neotropical region with sloths as the first vertebrate hosts. Infected porcupines and other mammals carried the infections across the Panamanian land bridge into North America and eventually across Beringia into Eurasia [63]. The presence of Paleoleishmania in Early Cretaceous Myanmar amber sand flies supports the former of these two theories.

If leishmaniasis did evolve in the Old World, just when it arrived in the New World is a mystery. However, a Dominican amber fossil provides a minimum date of some 20-30 million years. The evidence was in a Lutzomyia sand fly that was vectoring Paleoleishmania neotropicum [64] (Figure 32). In the proboscis of this Dominican amber sand fly were promastigotes (Figure 33), paramastigotes (Figure 34), and a group of amastigotes (Figure 35). Amastigotes are only formed in the vertebrate host and are normally ingested with

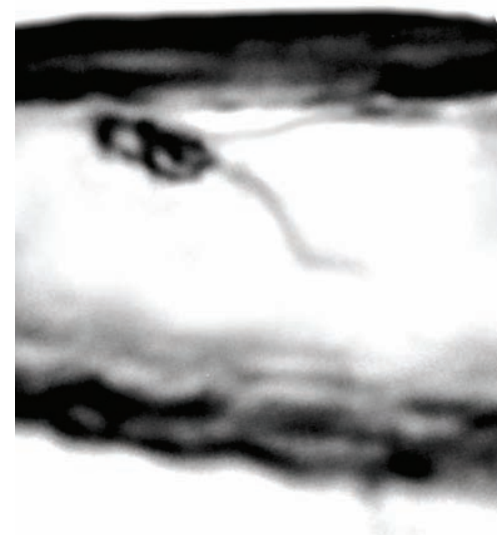

FIgUre 34: Two paramastigotes of Paleoleishmania neotropicum in the proboscis of the Dominican amber sand fly shown in Figure 32.

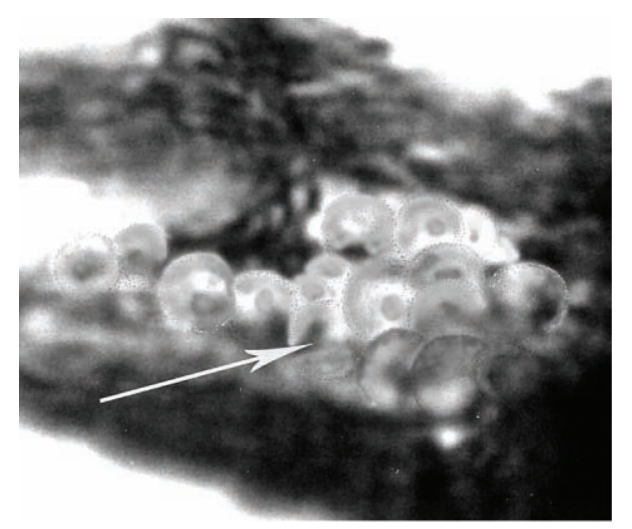

Figure 35: A cluster of amastigotes (arrow) of Paleoleishmania neotropicum in the proboscis of the Dominican amber sand fly shown in Figure 32.

the blood meal. The flagellates may have been multiplying in the proboscis since in Leishmania chagasi, amastigotes may divide during their transformation into promastigotes [65-67]. The promastigotes and paramastigotes (metacyclic stages) are produced inside the gut of the sand fly and indicate that there were at least two blood meals taken. Whether the origin and evolution of the New World sand fly Leishmania were the same as those of the Old World cannot be determined but they could have evolved independently of one another.

Biting midges are also vectors of trypanosomes, especially those infecting birds. Some idea of the antiquity of biting midges transmitting trypanosomes was the discovery of the Early Cretaceous Myanmar amber Leptoconops nosopheris. The body of the fossil biting midge had partially cleared, revealing trypanosomes of Paleotrypanosoma burmanicus in its midgut (Figure 36). Trypanosomes also occurred in the head, salivary glands, and salivary ducts of L. nosopheris and some flagellates were in a salivary droplet that collected on the tip of the proboscis (Figure 37) [68]. Extant 


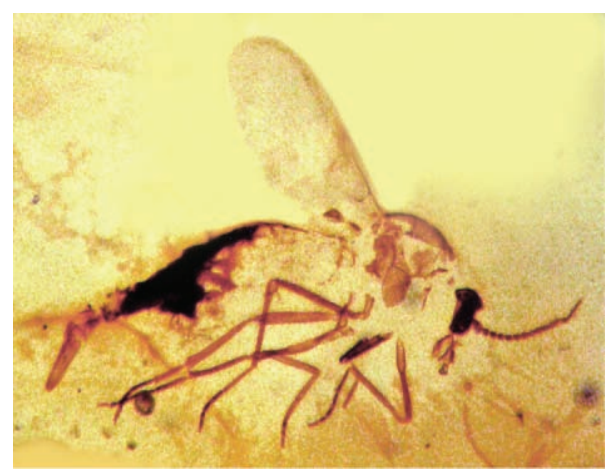

Figure 36: The Early Cretaceous Myanmar amber biting midge, Leptoconops nosopheris, a vector of the trypanosomatid, Paleotrypanosoma burmanicus.

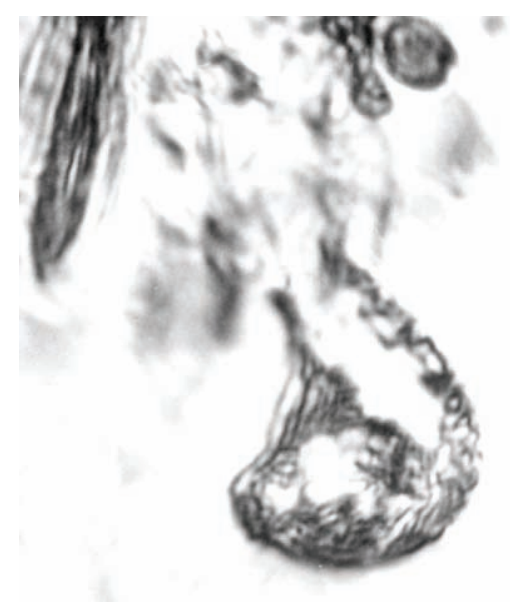

Figure 37: Stages of Paleotrypanosoma burmanicus in a salivary secretion protruding from the proboscis of the Early Cretaceous biting midge shown in Figure 36.

species of Leptoconops feed on reptiles, birds, and mammals; however, based on its age and characters resembling those found on extant reptile feeders, the vertebrate host of Paleotrypanosoma burmanicus was suspected of being a reptile $[69,70]$. Molecular techniques indicated that vertebrate parasitism by trypanosomes evolved multiple times in the past [71]. It is possible that biting midges were the original ancestral vectors of the Trypanosoma lineage, since Leptoconops clades extend back at least 120 million years [72].

Flies are not the only insect vectors of trypanosomes. Kissing bugs (Hemiptera: Reduviidae) are well known for their bloodsucking habits (Figure 38) and they transmit the devastating Chagas disease (Trypanosoma cruzi) in the American tropics. Two fecal droplets containing metatrypanosomes of Trypanosoma antiquus (Figure 39) were adjacent to a fifth instar nymph of Triatoma dominicana in Dominican amber (Figure 17). The fossil metatrypanosomes resemble those of T. cruzi. Analysis of mammalian hairs adjacent to the fecal droplets indicates that the vertebrate host for both the triatomine and trypanosomatid probably was a bat. Extant triatomines not only feed on bats but also are the

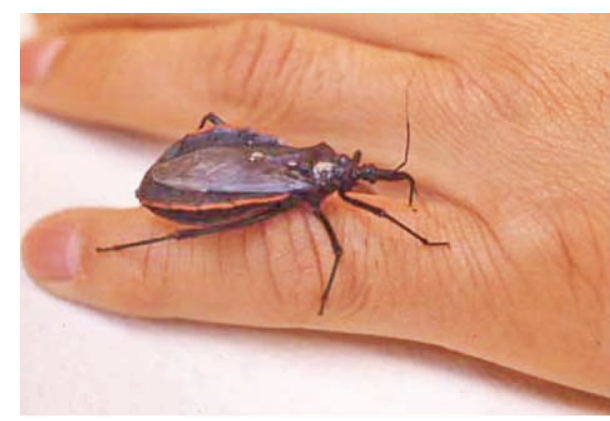

Figure 38: Kissing bugs (Hemiptera: Reduviidae), such as this extant Dipetalogaster sp., transmit Trypanosoma cruzi to humans in the American tropics.

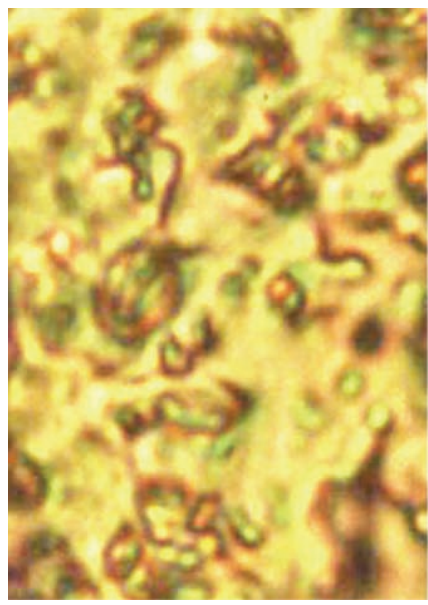

FIgURE 39: Metatrypanosomes of Trypanosoma antiquus in a fecal droplet of the Dominican amber Triatoma dominicana shown in Figure 17.

suspected vectors of all New World bat trypanosomes [7375]. It is possible that some lineages of trypanosomes evolved in bats and that these mammals were the original vertebrate hosts in Central and South America. Additional evidence of a long association between bats and trypanosomes is the absence of disease symptoms in these mammals [73]. Records of Chagas disease in humans date back to 4,000-year-old mummies in the Atacama Desert [76].

Other types of flagellates have been discovered in triatomines. Epimastigotes of a species of Blastocrithidia were detected in an anal droplet of Panstrongylus hispaniolae in Dominican amber (Figures 40 and 41) [77]. The fossil flagellates are similar in size and shape to the epimastigotes of Blastocrithidia triatomae that were described from the intestine of Triatoma infestans [78]. Blastocrithidia can be pathogenic in triatomes when populations built up in the midgut [79].

One of the most notorious protozoan diseases of humans is malaria and aside from episodic epidemics of plague and cholera, malaria continues to cause human suffering in many parts of the world today. That may be because malarial organisms are the ultimate pathogens. Few other pathogens 


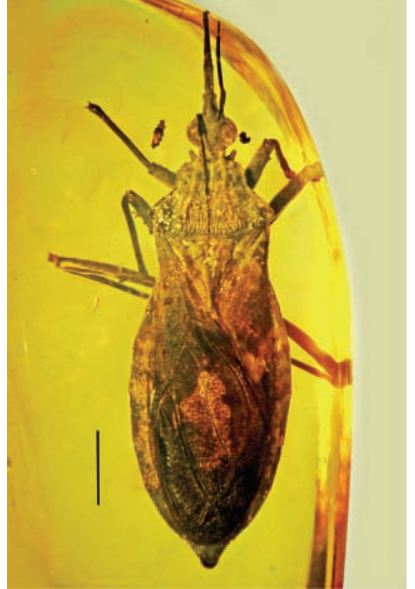

Figure 40: A Kissing bug, Panstrongylus hispaniolae, in Dominican amber.

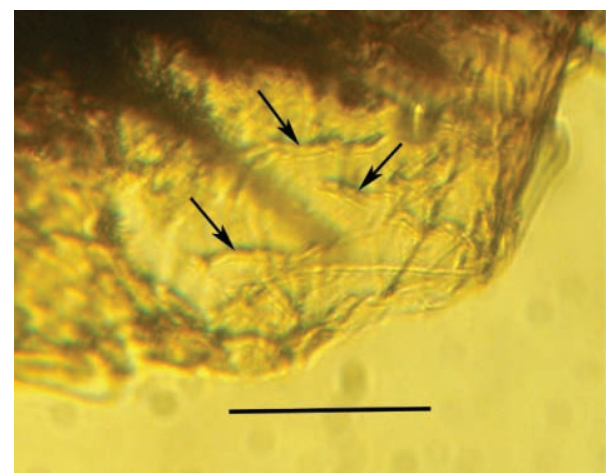

Figure 41: Epimastigotes (arrows) of a Blastocrithidia sp. protozoan in the anal droplet of Panstrongylus hispaniolae depicted in Figure 40. Bar $=77 \mu \mathrm{m}$.

have the ability to change their surface coat so readily as modern day Plasmodium.

A separate lineage of ancient malarial organisms is vectored by biting midges that date back 100 million years. These primitive malaria-biting midge associations still survive today in various parts of the world. The earliest evidence of malaria was obtained from a partially cleared female biting midge (Protoculicoides sp.) in Early Cretaceous Myanmar amber [80] (Figure 42). A number of developing oocysts and sporozoites of the malarial parasite, Paleohaemoproteus burmacis, were inside the abdomen of the biting midge (Figure 43). Morphological features of the vector were used to determine that the host was large and cold-blooded [81]. Likely hosts in Early Cretaceous Myanmar were lizards, crocodilians, and dinosaurs [25].

The development of Paleohaemoproteus burmacis was probably very similar to malarial parasites vectored by biting midges today. During blood feeding, the female vector acquires vertebrate blood cells infected with gametocytes. After their release from the vertebrate blood cells in the stomach of the biting midge, the gametocytes unite and initiate the zygote or sporogonic stage of the life cycle. The

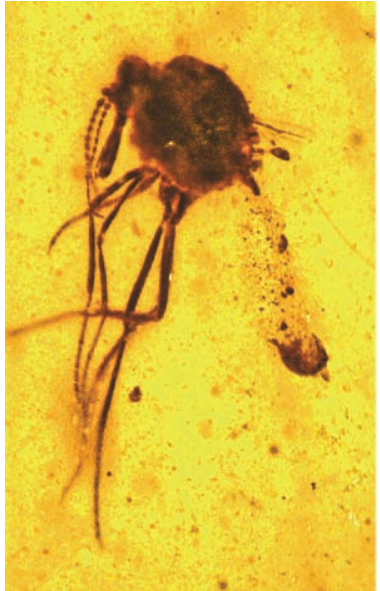

Figure 42: The Early Cretaceous Myanmar amber biting midge (Protoculicoides sp.) with its malarial pathogen, Paleohaemoproteus burmacis.

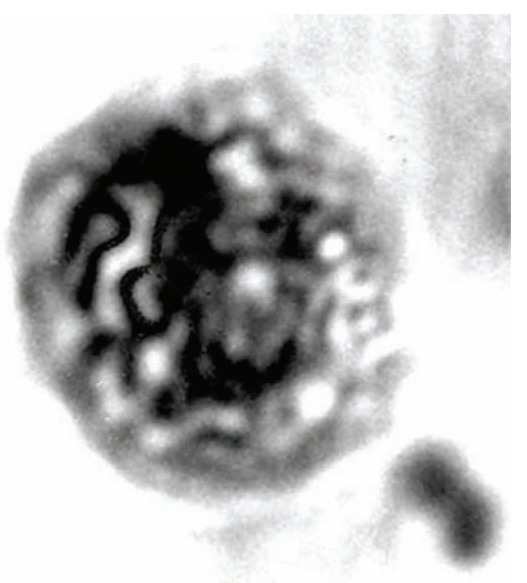

Figure 43: An oocyst of Paleohaemoproteus burmacis developing in the body cavity of the Early Cretaceous biting midge depicted in Figure 42. Sporozoites are developing inside the oocyst.

zygote differentiates into a motile ookinete, which penetrates the epithelial cells of the insect's midgut and forms an oocyst. Vertebrate-infective sporozoites develop within the oocysts (Figure 43) and when released, they migrate to the salivary glands. They are introduced into a vertebrate during subsequent blood meals.

Paleohaemoproteus burmacis has many characteristics of the extant genus Haemoproteus that are vectored by biting midges to birds and reptiles [82-87]. Today haemoproteid malaria caused by Haemoproteus spp. is commonly transmitted by Culicoides biting midges $[82,88]$.

Discovering Plasmodium malaria in the Dominican amber mosquito, Culex malariager, showed that not all lineages of human malaria evolved in the Old World $[89,90]$ (Figure 44) and were later introduced into the New World. Now we know that at least one lineage of Plasmodium malaria was being vectored by mosquitoes in the Americas some 2030 mya [90]. Inside the fossil Culex malariager were various 


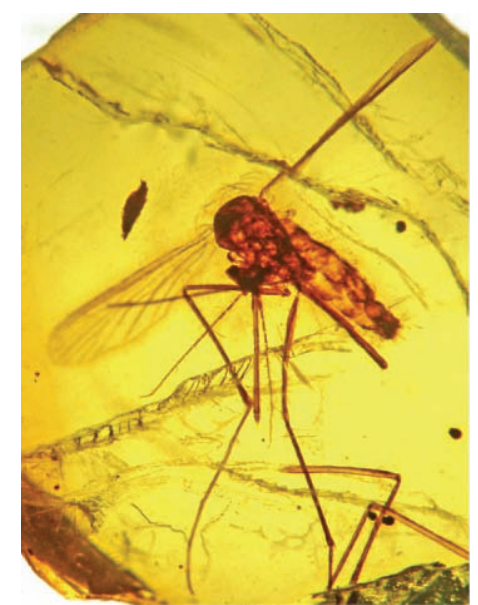

Figure 44: The Dominican amber mosquito, Culex malariager, a vector of the malarial pathogen, Plasmodium dominicana.

stages (oocysts, sporozoites, ookinete, and microgametocyte) of Plasmodium dominicana. Two oocysts were entire (Figure 45); however, two others had ruptured and groups of sporozoites were moving into the hemocoel (Figure 46). Some of the released sporozoites had managed to reach the salivary glands before the mosquito became entrapped.

The large, pedunculated oocysts aligned Plasmodium dominicana with the extant bird parasite, Plasmodium juxtanucleare, which is transmitted by Culex spp. [83, 91]. This latter species had been assigned a basal position among avianinfecting Plasmodium species [91], suggesting that the genus Plasmodium could have evolved with birds in the Mesozoic with Cretaceous culicine mosquitoes as vectors [92].

The Plasmodium dominicana lineage could easily have been transferred from birds to mammals by culicine mosquitoes since such lateral transfers of malaria from birds to mammals occur naturally and have been demonstrated experimentally $[83,93,94]$. Once established in mammals, anopheline mosquitoes, such as the Dominican amber Anopheles dominicanus, could have transmitted Plasmodium from simians to humans [95]. Another possible pathway is that anopheline mosquitoes could have acquired infections directly from birds and passed them on to mammals, including simians. So the evolution of human malaria in the New World could have begun in birds and then shifted to mammals and finally to humans. Human malaria in the Old World may have evolved by a completely different pathway but probably also existed millions of years ago. The discovery of Plasmodium falciparum malaria in Egyptian mummies using antigen immunoassay techniques establishes the disease in humans at a minimum date of 3200 B.C. $[96,97]$.

Fossils provide no clues of how Plasmodium evolved from free-living ancestors; however, I believe that the original host in a vector association is the one in which the sexual stages of the parasite occur, which in the case of malaria would be the mosquito. A possible scenario is that the free-living aquatic

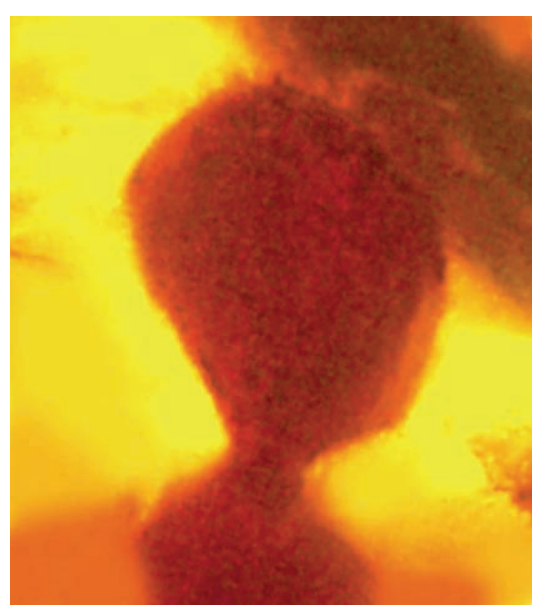

Figure 45: An oocyst of Plasmodium dominicana in the hemocoel of the Dominican amber mosquito shown in Figure 44.

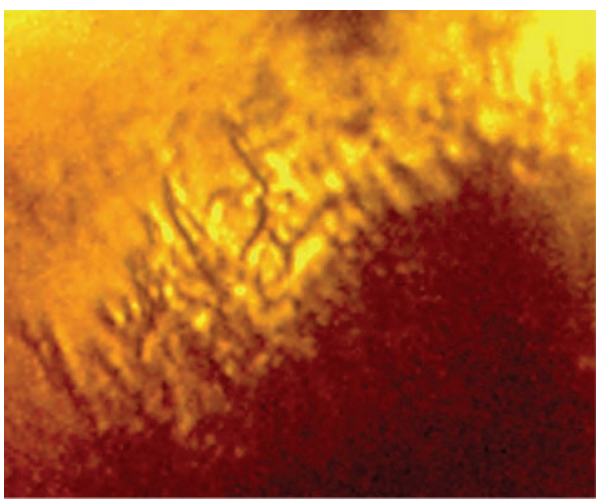

FIgURE 46: Sporozoites emerging from an oocyst of Plasmodium dominicana in the Dominican amber mosquito shown in Figure 44.

ancestors of Plasmodium were first acquired by mosquito larvae. The parasites were then carried through the pupa stage into the next generation of adults and this single host cycle was established. Eventually, some sporozoites entered the salivary glands and were transferred into vertebrates. Their establishment in the liver and blood cells served to protect them from host defense responses.

An opposing but less likely evolutionary scenario is that Plasmodium was originally a blood parasite of vertebrates that reproduced by merozoite division. Mosquitoes ingested vertebrate blood cells infected with merozoites and over time the released merozoites began to diversify and eventually a sexual stage was established in mosquitoes. This resulted in the establishment of a sporogonic stage with the production of vertebrate-infective sporozoites.

There are numerous types of malaria in a wide range of vertebrates; however, very few have left a fossil record. A rare malarial pathogen was discovered in a Dominican amber streblid bat fly, Enischnomyia stegosoma (Figure 47) $[98,99]$. Two ovoid oocysts of Vetufebrus ovatus attached to the midgut wall of the bat fly contained short, stubby sporozoites (Figure 48) and similar sporozoites in the salivary 


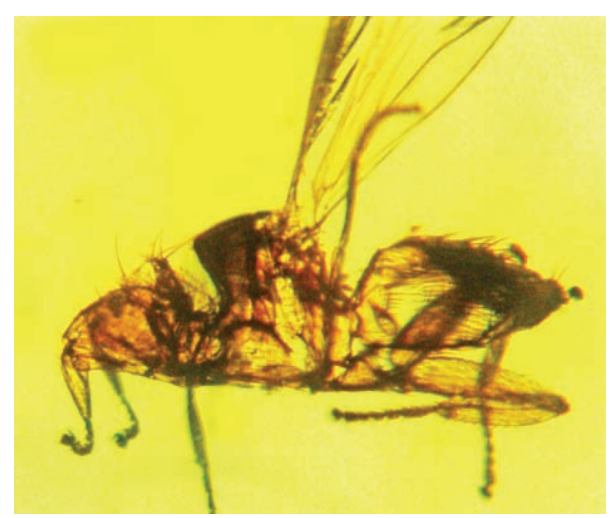

FIgURE 47: A Dominican amber bat fly, Enischnomyia stegosoma, vector of the malarial pathogen, Vetufebrus ovatus.

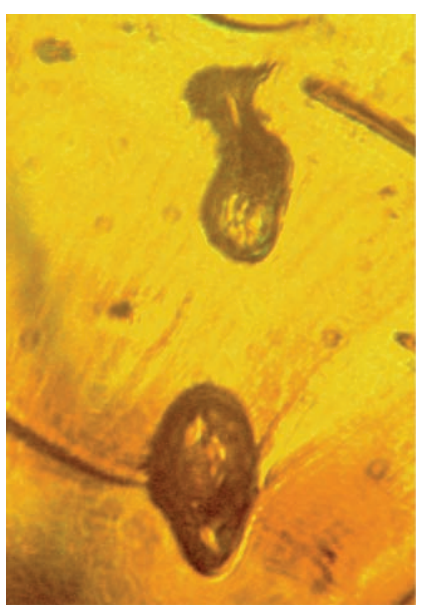

FIGURE 48: Two oocysts with developing sporozoites of Vetufebrus ovatus in the Dominican amber bat fly shown in Figure 47.

glands and ducts indicated that representatives of Neotropical Hippoboscoidea were vectoring malaria to bats in the Cenozoic.

Protozoans cause a number of alimentary tract infections in all vertebrates; however, the origins of such infections are difficult to determine. They probably date back to the early evolution of vertebrates since the passage of microbes into the lumen of the alimentary tract would have occurred from eating infested food. The establishment of some of these microbes, at least for short periods, would have occurred multiple times. Reptiles were one of the early hosts of intestinal protozoan diseases [100] as shown by the discovery of mature cysts of Entamoebites antiquus in a dinosaur coprolite from the Early Cretaceous Bernissart Iguanodon shaft in Belgium [101] (Figure 49). The fossil cysts resembled species in the widespread modern genus Entamoeba that infect amphibians, reptiles, birds, and mammals. The extant E. invadens destroys leucocytes and causes disease in reptiles when it invades the liver and causes hepatitis and nephritis. Common symptoms of gastrointestinal infections in lizards

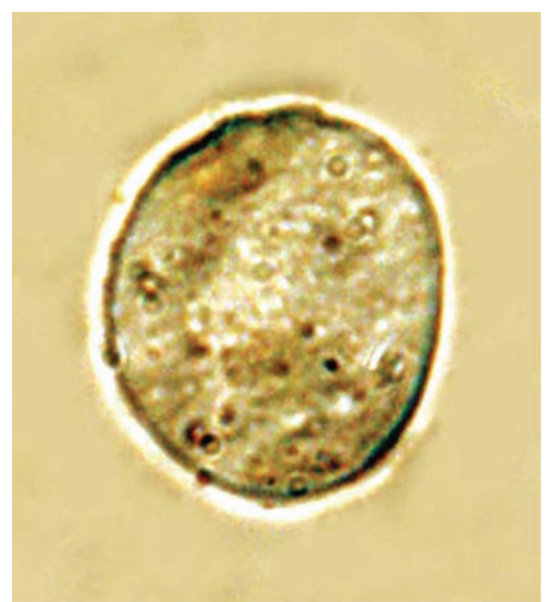

Figure 49: An Early Cretaceous cyst of Entamoebites antiquus recovered from a dinosaur coprolite at the Bernissart Iguanodon shaft in Belgium.

and snakes are vomiting and severe diarrhea [102-104]. Entamoebites antiquus provides a minimum date when pathogenic protozoa were established in the gut of vertebrates.

There is widespread subfossil evidence of intestinal pathogens based on samples from coprolites, latrines, and cesspits. Using an immunoassay test for determining the presence of adhesion antigens, the pathogenic Entamoeba histolytica could be detected in human samples from Brazil 6000 to $5000 \mathrm{BP}$ [105]. A review of human intestinal parasites from around the world based on the microscopic examination of treated samples has been recently summarized [106].

Gregarines are a very complex group of protozoans that evolved as monoxenous parasites of invertebrates [107, 108]. Their origins are enigmatic since there are no closely related free-living forms; however, since they parasitize a wide variety of marine and terrestrial invertebrates, gregarines are certainly an ancient group. Gregarines parasitize a wide range of insects today, including a number of cockroaches, which may have been one of the original host groups [109]. Discovering trophozoites and oocysts of Primigregarina burmanica from an Early Cretaceous Myanmar amber cockroach showed that the basic developmental stages of extant gregarines were firmly established some 100 million years ago [110, 111] (Figures 50 and 51).

2.4. Fungi. Fungal pathogens are ubiquitous and parasitize a wide range of animals and plants; however, actual evidence of parasitism is rare. Most fossil examples of animal-parasitic fungi occur on arthropods in amber and in many cases, the fungi can usually be placed in extant families and genera. The oldest evidence of animal parasitism by fungi is the insect pathogen, Paleoophiocordyceps coccophagus, parasitizing a scale insect in Early Cretaceous Myanmar amber [112]. Two synnemata covered with a palisade of elongated cylindrical phialides bearing conidia at their tips had emerged from the insect (Figures 52 and 53). Evidence indicated that the hypocrealean ancestor of $P$. coccophagus evolved in the Early 


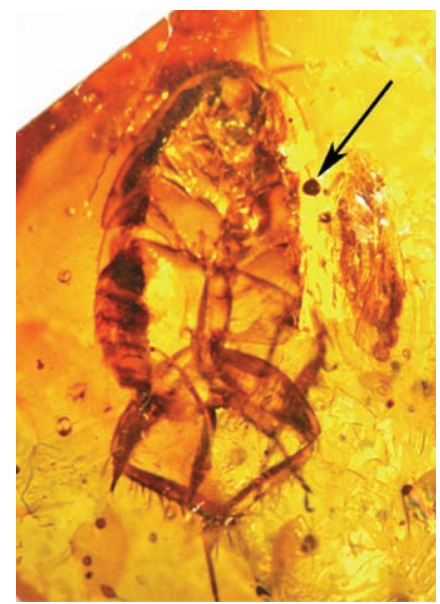

FIgURE 50: An Early Cretaceous Myanmar amber cockroach adjacent to a gametocyst (arrow) of the gregarine protozoan parasite, Primigregarina burmanica.

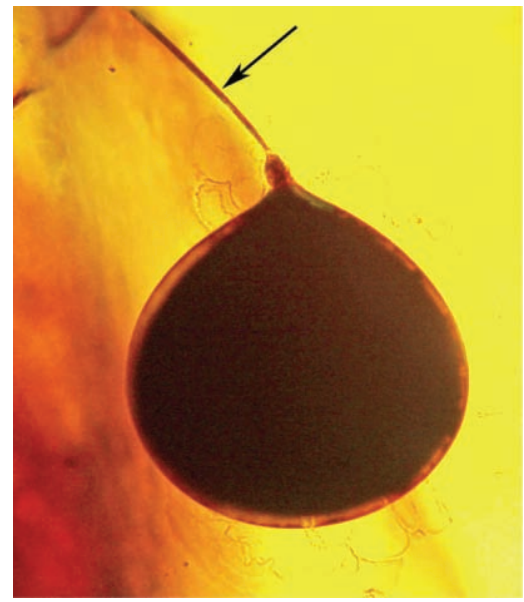

FIGURE 51: Detail of the gametocyst of the gregarine parasite, Primigregarina burmanica that was released from the gut of the Early Cretaceous cockroach shown in Figure 50. Arrow shows a sporefilled sporoduct.

Jurassic (193 mya) as a plant parasite that later shifted to animal hosts [112].

Additional examples of fungal pathogens of insects in amber include a member of the Entomophthorales infecting a winged termite in Dominican amber [113]. The termite was covered with a white mat of mycelium that had produced budding conidia, characteristic of extant members of the genus Entomophthora (Figure 54). Another Entomophthorales infection was found on a fungus gnat in Dominican amber. The fungus formed a felt-like hymenium over the back of the fly (Figure 55), which is very similar to the growth pattern of Entomophthora infections on extant fungus gnats [6].

A Dominican amber Azteca ant heavily infected with a species of the extant genus Beauveria (Figure 56) establishes

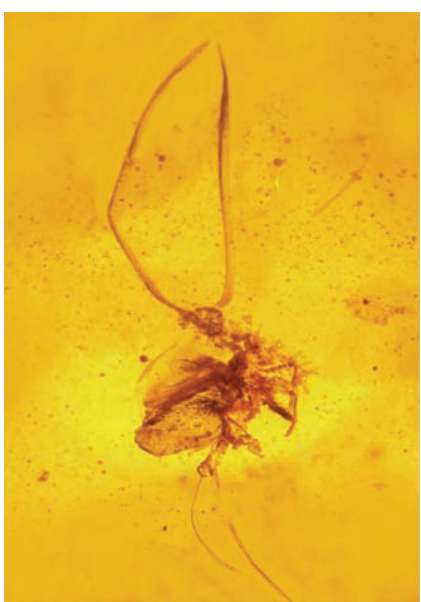

Figure 52: Two extended synnemata of the Early Cretaceous Myanmar amber fungus, Paleoophiocordyceps coccophagus, emerging from the top of a scale insect (Albicoccidae).

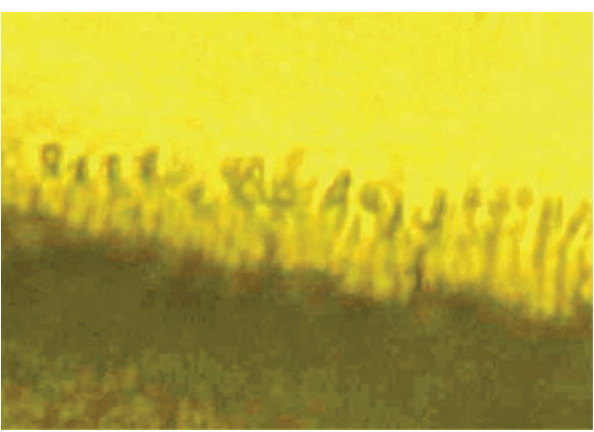

FIgURE 53: A layer of conidiogenous cells and conidia on the surface of one of the synnemata of the Early Cretaceous fungus shown in Figure 52.

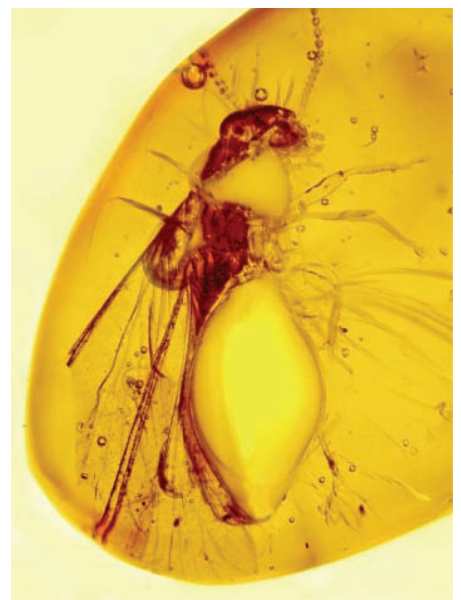

FIGURE 54: A Dominican amber termite bearing white colonies of an Entomophthorales fungus. 


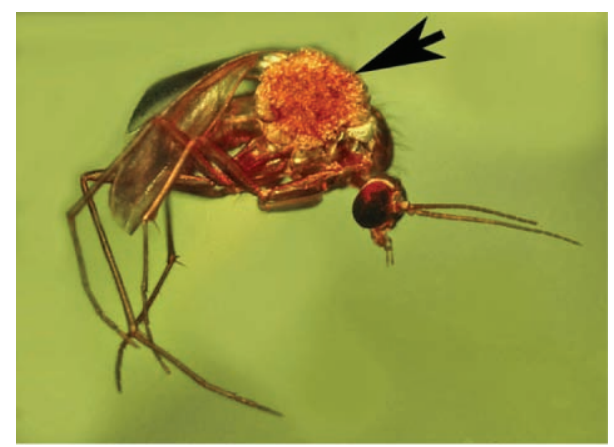

FIgURE 55: An entomophthorales infection of a fungus gnat in Dominican amber. The fungus formed a felt-like hymenium (arrow) on the fly.

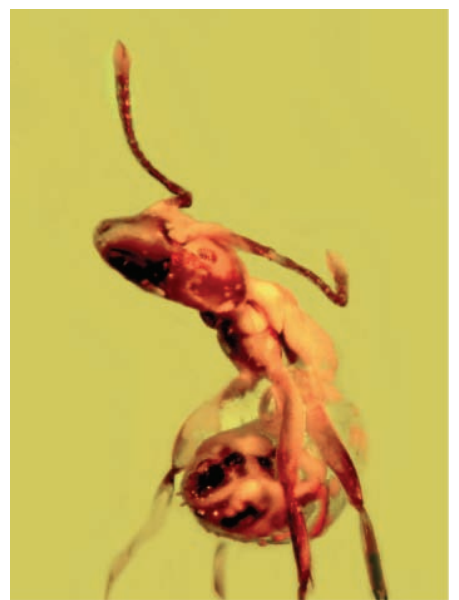

FIgURE 56: Dominican amber Azteca worker ant infected with a Beauveria fungus.

a minimum date for the appearance of that clade. Conidiophores and conidia of the fungus covered portions of the ant's body [114] (Figure 57).

The Trichomycetes comprise a group of cosmopolitan, microscopic fungi that parasitize a wide range of arthropods. A member of this order found on a Culex mosquito in Dominican amber establishes a minimum date for this group. Several types of thalli had emerged from between the junctions of the abdominal tergites on the back of the mosquito [6] (Figure 58). Some were slender, elongate forms that were producing trichospores while others were short and swollen (Figure 59).

Some additional examples of fungal pathogens in Dominican amber are a synnemata produced by a Hirsutella-like fungus on a Troctopsocopsis bark louse (Figure 60) and an undescribed fungus emerging from a winged ant (Figure 61).

Evidence of pathogenic fungi attacking nematodes was found among a population of the mycetophagous nematode, Oligaphelenchoides atrebora, in Mexican amber [30]. The inner tissues of infected nematodes had been replaced by fungal mycelia (Figure 62), some of which were sporulating (Figure 63) [115].

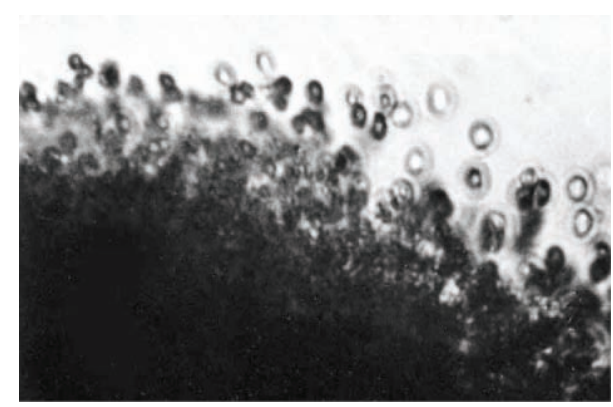

FIGURE 57: Conidiophores and conidia of the Beauveria fungus growing on the Dominican amber Azteca ant depicted in Figure 56.

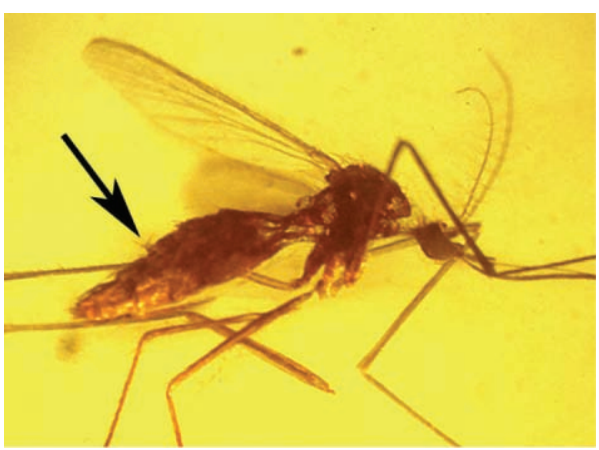

FIGURE 58: Group of thalli (arrow) of a trichomycete fungus emerging between the abdominal tergites of a Culex mosquito in Dominican amber.

Ancient fungal pathogens of vertebrates are quite rare; however, a case of coccidioidomycosis was reported in two Holocene bison dated at $8500 \mathrm{BP}$ [116]. Spheres and endospores of the pathogen were found in the mandibles and adjoining bones of the bison. The subfossil stages were similar to those of extant species of Coccidioides, a genus that infects a wide range of vertebrates, including humans. This discovery sets a locality and minimum time for the occurrence of vertebrate parasitic Ascomycetes. It is interesting that humans are considered one of the vectors of this disease, dispersing it as they migrated between North and South America [116]. Skeletal pathology in a Native American dated at 1,000 to 1,400 A.D. was attributed to coccidioidmycosis when a microscopic examination revealed both spherules and endospores of Coccidioides immitis [117].

There are numerous reports of fossil fungi on plants dating from the Palaeozoic onwards. However, few of these show the actual pathogen in association with their plant host. Many of these reports have been summarized previously $[3,118]$. The fossil record of fungi begins in the Ordovician, some 460 mya [119], although molecular estimates of fungal phylogeny place the origin of terrestrial fungi (Ascomycota, Basidiomycota, and Glomales) in the Proterozoic [120].

The origins of plant pathogenic fungi may have begun with simple hosts such as algae and fungi. Fungal parasitism of Early Devonian algae (400 mya) probably represents one of the first host parasitic associations with fungi [121]. The same is true for mycoparasitism where fungi parasitize other fungi. 


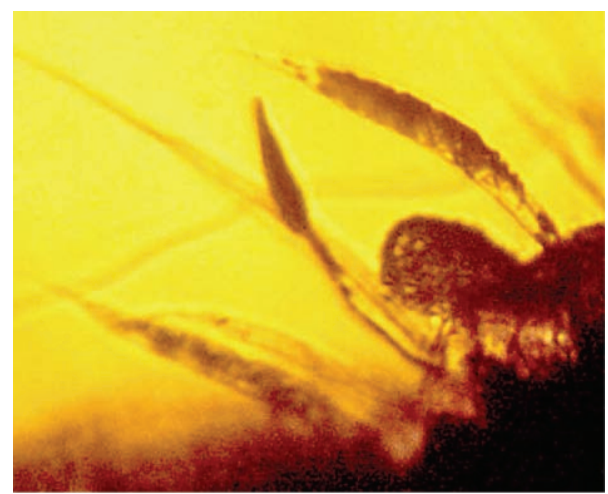

FIGURE 59: Slender, narrow thalli, and a short, swollen thallus of the trichomycete fungus parasitizing the Dominican amber Culex mosquito depicted in Figure 58.

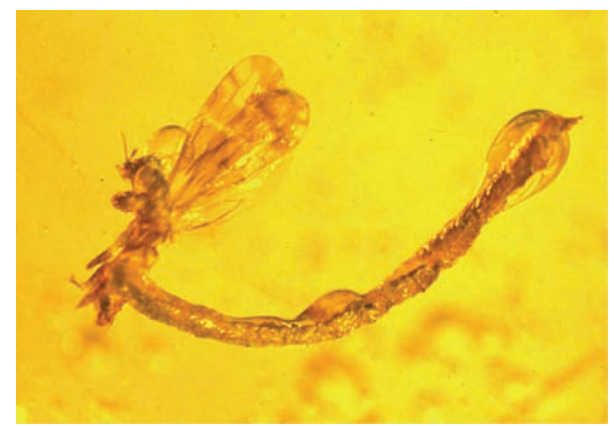

FIGURE 60: Synnematium of a Hirsutella-like fungus parasitizing a bark louse in Dominican amber.

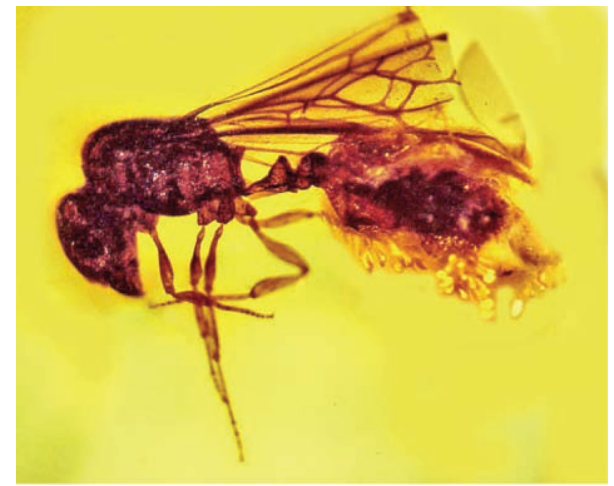

FIGURE 61: A fungus sporulating on the abdomen of a winged ant in Dominican amber.

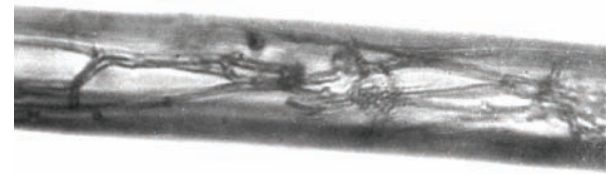

FIgURE 62: Fungal hyphae inside the body of the nematode, Oligaphelenchoides atrebora, in Mexican amber.

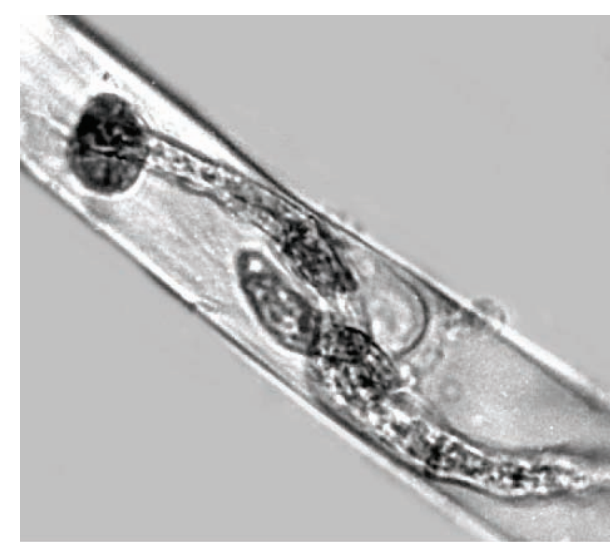

FIGURE 63: Developing spore of a fungal pathogen inside the body of the nematode, Oligaphelenchoides atrebora, in Mexican amber.

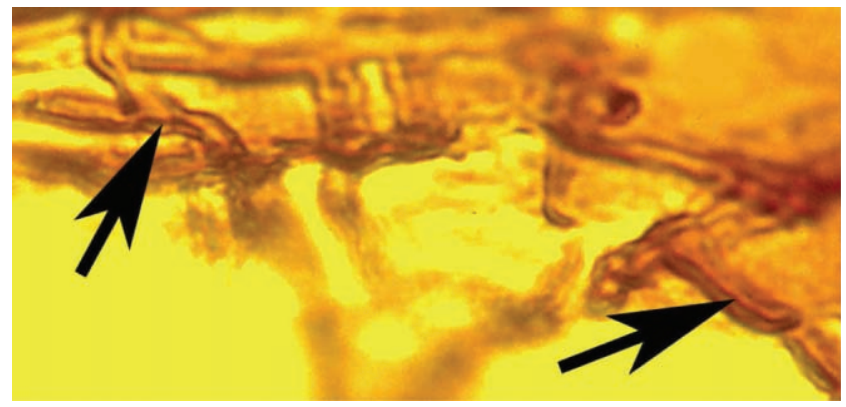

FIgURE 64: Parasitic and hyperparasitic fungi (arrows) developing on an agaric mushroom in Early Cretaceous Myanmar amber.

Records of such associations have been found in Devonian deposits [122] and in Early Cretaceous amber, where an agaric mushroom was parasitized by a fungus that in turn was parasitized by a second hyperparasitic fungus [123] (Figure 64). Fungi were probably the first parasites of vascular plants. An early record of pathogenic fungi associated with a vascular plant is the 400 mya Devonian Paleopyrenomycites devonicus that was developing in the cortex of aerial stems and rhizomes of the primitive Asteroxylon (Figure 65) [124]. Rust and smut fungi are also probably very primitive although thus far, only a Tertiary record of a smut fungus infecting an Eocene angiosperm in British Columbia is known [125].

Spot fungi are an interesting heterogeneous group that evolved various methods of either penetrating surfaces of leaves and petals or entering through natural openings (stomata). Fossil records of leaf spot fungi have been reviewed and date back to the Late Carboniferous [3, 126]. Some fossil spot fungi occurred on a petal in Mexican amber and on a dicot and monocot leaf in Dominican amber [127]. Several pycnidia of Leptothyrites dominicanus were present on the monocot leaf (Figure 66) and one pustule contained conidiophores and conidia (Figure 67).

Most groups of parasitic fungi probably evolved from saprophytic species developing on dead arthropods and plants. Physiological adaptations allowing them to attack 


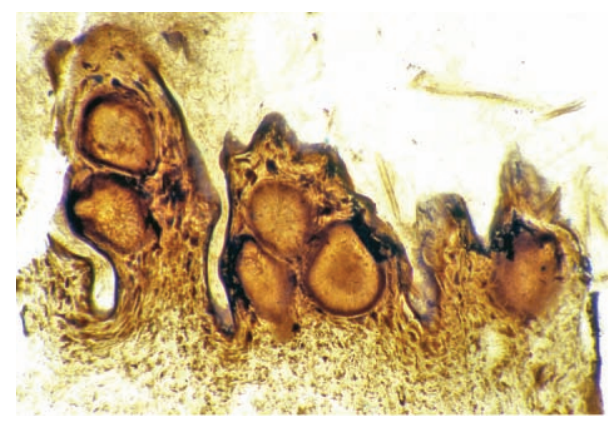

Figure 65: Perithecia of the Devonian ascomycetous fungus, Paleopyrenomycites devonicus, developing in the vascular plant, Asteroxylon, at the Early Devonian Rhynie chert site (Photo courtesy of T. N. Taylor).

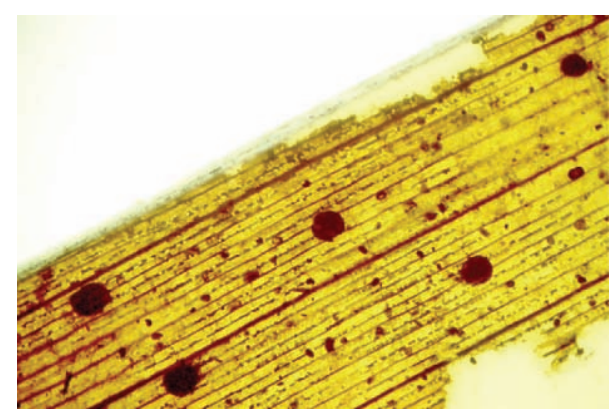

FIGURE 66: Five spherical, dark pycnidia of the coelomycete, Leptothyrites dominicanus, parasitizing a monocot leaf in Dominican amber.

dying or weakened animals and plants could have been further modified for entering and obtaining nourishment from healthy organisms.

\section{Multicellular Endoparasites}

3.1. Nematomorpha. Hairworms are an ancient group of arthropod parasites that live inside invertebrates and usually kill the latter when their development is completed. A specimen in Early Cretaceous Myanmar amber provides a minimum date of $100 \mathrm{my}$ for their existence [128]. Evidence that they parasitized cockroaches in the Tertiary is shown by the hairworm, Paleochordodes protus, emerging from a blattid in Dominican amber [129] (Figure 68). Since this group of parasites is not closely related to any existing freeliving or parasite group, it is difficult to determine their origins and evolutionary development. Hairworms appear to be an ancient group that arose independently and successfully maintained themselves to the present, in spite of ongoing environmental disruptions that are destroying their host's habitats.

3.2. Nematodes. Nematodes are another primitive group that has no close affinity to any extant invertebrate group and the lineage from which they evolved is probably extinct. Thus attempting to trace their origins is highly speculative,

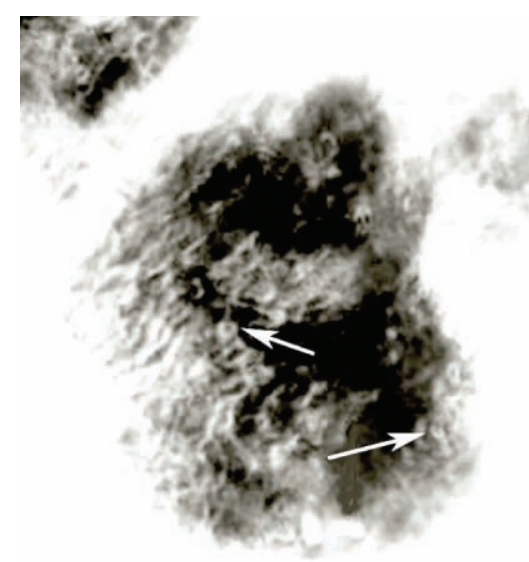

Figure 67: Conidia (arrows) inside one of the pycnidia of Leptothyrites dominicanus shown in Figure 66.

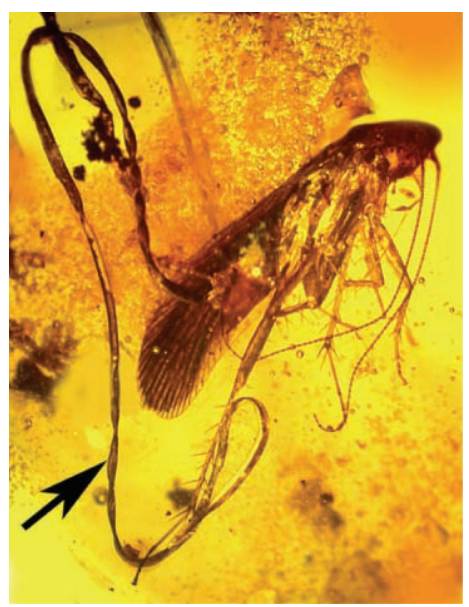

FIgUre 68: The hairworm, Paleochordodes protus (arrow), emerging from a cockroach in Dominican amber.

even with molecular techniques. It is possible that nematodes originated in the sea and first parasitized marine invertebrates and vertebrates in the Cambrian. The most complete fossil record of any particular nematode group is of the Mermithidae, a group well represented in amber and easily detected as they are leaving or have just emerged from their arthropod hosts.

Mermithid nematodes superficially resemble hairworms in size and development. They parasitize a wide range of terrestrial invertebrates and probably evolved from freeliving dorylaimids or mononchs. A recent study reported free-living dorylaimids that had entered the body cavity of some terrestrial insects, thus showing a possible first step in an evolutionary scenario indicating that mermithids evolved from free-living Dorylaimida [130].

Many mermithids parasitize small flying insects, which is why the most complete record of their evolutionary history is in amber. Evidence in Early Cretaceous Lebanese amber suggests that chironomid midges or their ancestors were the original insect hosts of mermithids (Figure 69) [131]. 


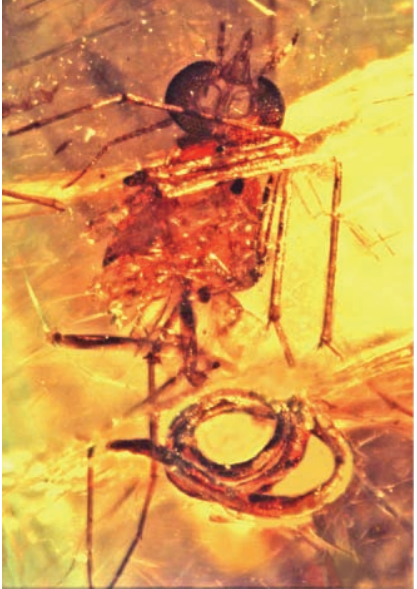

Figure 69: Parasitism of an Early Cretaceous Lebanese amber chironomid midge by the mermithid nematode, Cretacimermis libani. The nematode is coiled in the abdomen of its host.

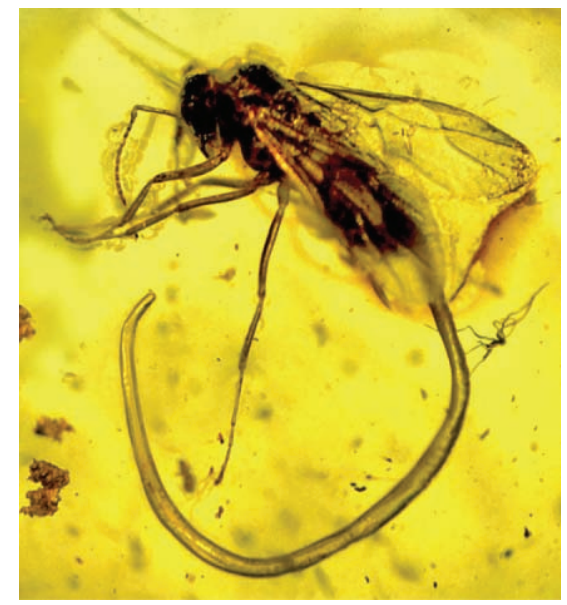

Figure 70: Parasitism of a Baltic amber ant by the mermithid nematode, Heydenius formicarius.

However based on the earliest fossil record of all their host groups, an estimated date for the origin of mermithids would be in the Permian [15]. Evidence that mermithids had diversified by the mid-Tertiary is provided by a wide range of parasitized hosts, including ants (Figure 70), hemipterans (Figure 71), trichopterans (Figure 72), and arachnids in Baltic and Dominican amber $[15,132]$.

Several clades of the nematode group Tylenchomorpha also parasitize insects and among these the acugutturids, iotonchids, allantonematids, and sphaerulariids have a fossil record. Those with the greatest selection of hosts are the Sphaerularidae and Allantonematidae. In contrast to mermithids that only mature but do not multiply in their hosts, the small size of these tylenchomorphs allows them to undergo one or even two generations inside their host. Often the juveniles can be observed within the body cavity or emerging from various parts of insects in amber. Fossil records of sphaerulariids and allantonematids include species parasitizing beetles, ants, and flies in Tertiary amber [15].

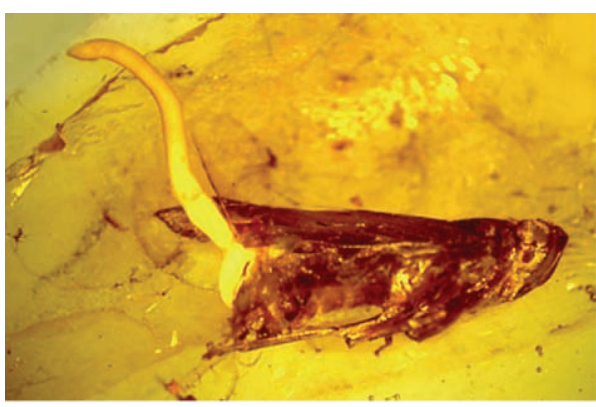

FIGURE 71: The mermithid nematode, Heydenius brownii, emerging from a planthopper in Baltic amber.

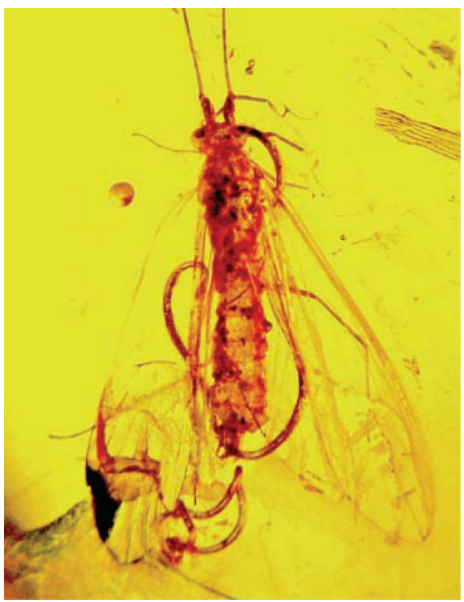

FIgure 72: Two mermithid nematodes, Heydenius trichorosus, adjacent to their caddis fly host (Triaenodes balticus) in Baltic amber.

The earliest fossil record of sphaerulariids is Tripius balticus that was parasitizing a sciarid fly in Baltic amber. However, based on the earliest fossil record of their host group, an estimated date for the origin of sphaerulariids would be in the Jurassic [15].

The Dominican amber Palaeoparasitylenchus dominicanus establishes a location and minimum time when drosophilid flies were victimized by allantonematids. However, based on the earliest fossil record of their host group, an estimated date for the origin of allantonematids would be in the Permian [15]. Using the same criterion, an estimated date for the origin of the iotonchids would be in the Cretaceous [15]. However, the oldest fossil record of an iotonchid is Paleoiotonchium dominicanum in a parasitized fungus gnat in Dominican amber. The iotonchids are especially interesting since they provide evidence that insect parasitic tylenchomorphs evolved from mycetophagous clades. While the life cycle of the fossil Paleoiotonchium dominicanum remains unknown, it is probably similar to that of its recent descendant, Iotonchium californicum, that was studied in California [133]. This latter species has two alternating life cycles, a fungal feeding cycle with the nematodes developing on mushrooms and an insect-parasitic cycle where development only occurs inside the body of a fungus gnat that feeds on the mushroom. Iotonchium is a nematode that 
has the ability to utilize both fungi and insects as hosts. It appears to be at a stage in its evolution that is ready to sever the ties with the more primitive fungal portion of its life cycle.

A representative of the acugutturid moth parasites, Setonema protera, also occurs in Dominican amber; however, based on the earliest fossil record of its host group, an estimated date for the origin of this group would be in the Carboniferous [15].

Representatives of the nematode suborder Rhabditina are mainly microbotrophic free-living nematodes; however, some lineages developed amazing specialized patterns of parasitism. One of these lineages is a member of the family Diplogasteridae that evolved the ability to parasitize fig wasps. Diplogasterids are common inhabitants of soil and decaying organic matter and their associations with arthropods are mainly phoretic in nature. Yet some of these nematodes became parasites of fig wasps. Fig wasps are very tiny hymenopterans that develop in fig synconia within the flower clusters. Their entire life cycle takes place in the fig with female flight patterns related to entering and exiting the fig flowers as they pollinate the new flowers and deposit their eggs. The Parasitodiplogaster lineage of diplogastrids is carried by the adult fig wasps to the fig flowers and then parasitizes the developing fig wasp larvae. Originally, the nematodes were probably strictly phoretic and developed on pollen and bacteria in the fig flowers, using the wasps only for transport. At some point, juvenile nematodes emerging from eggs deposited in the fig flowers entered the fig wasp larvae and adults. That this association has continued for 20-30 million years is evident from a parasitized fig wasp surrounded by released stages of the diplogastrid, Syconema dominicana, in Dominican amber [15]. However, based on the earliest fossil record of their host group, an estimated date for the origin of this nematode lineage would be in the Eocene [15].

Another unique mode of parasitism originated independently in two genera of rhabditine nematodes, Steinernema and Heterorhabditis. These two nematode genera evolved from separate lineages of free-living, bacterial-feeding, soil nematodes but developed a very similar pattern of insect parasitism. Each lineage became associated with its own specific insect-pathogenic bacteria that were originally acquired from the immediate environment. These bacteria are retained in the gut of the infective stage juveniles and released when the latter penetrate into a living insect. The released bacteria kill the insect within 24 hours and the nematodes feed on the tissues of the corpse that have been modified by the specific bacteria. These so-called entomopathogenic nematodes are sold commercially as biological control agents. The discovery of infective juveniles of one of these clades in Early Cretaceous Myanmar amber shows that entomopathogenic nematodes were present some 100 mya (Figure 10) [15]. The fossil infective stage Proheterorhabditis burmanicus was adjacent to a beetle that contained bacteria in its tissues similar to those carried by extant heterorhabditids (Figure 11) [134]. Based on the earliest fossil record of their host group, an estimated date for the origin of both the heterorhabditids and steinernematids would be in the Permian [15].
Helminthiasis refers to diseases of humans and animals caused by parasitic worms such as nematodes, trematodes (flukes), and cestodes (tapeworms). Past remains of vertebrate parasitic nematodes are mainly found in coprolites and corpses. Two common animal parasites are ascarids or stomach worms and oxyurids or pinworms. The oxyurids evolved from microbial soil inhabitants and it was not that large a step to shift from feeding on microbes in the environment to those in the gut lumen of invertebrates and vertebrates. The earliest record of an oxyurid parasitizing invertebrates is Paleothelastoma tipulae from an Early Cretaceous crane fly in Myanmar amber [15]. Based on the earliest fossil record of their host group, an estimated date for the origin of the invertebrate parasitic oxyurids would be in the Silurian [15].

Oxyurids found in subfossil deposits show the wide range of vertebrate hosts of these parasites. Syphacia was found in the remains of a 10,000-12,000-year-old ground squirrel in Eastern Russia [135], eggs of Parapharyngodon sceleratus were recovered from 9,000-year-old coprolites of an iguanid in Brazil [136], and juveniles of Agamofilaria oxyura were recovered from a 10,000 \pm 180 -year-old Shasta Ground Sloth bolus [137]. Based on the earliest fossil record of their host group, an estimated date for the origin of the vertebrate parasitic oxyurids would be in the Carboniferous [15].

It is difficult to determine when humans were first infected by the oxyurid pinworm, Enterobius vermicularis. In spite of the 10,000-year-old record from North America and molecular traces of E. vermicularis in 27 preColumbian coprolites ranging from 1,100 to 6,110 years in North and South America [138, 139], the first human infections were probably in the Old World, even though such records from archaeological sites are rare [106]. The oldest Old World records are from a 2100-year-old Chinese mummy [140] and surprisingly, the only report of pinworms in Egyptian mummies was from a site in Romanoccupied Egypt that dates from 30 to 395 AD [141]. However, the discovery of E. vermicularis in a chimpanzee [142] provides an avenue for early human infection in the Old World and peoples migrating across the Bering Strait could have brought this nematode to the New World [143].

Ascarids or stomach worms are probably the most common nematode parasites of vertebrates. The complicated life cycle of many ascarids, including the giant roundworm that infects humans, makes determining their early evolution difficult. Why it is necessary for the immature worms to traverse the wall of the intestine, migrate through the tissues of the host, and then return to small intestine to continue their development is perplexing. The oldest fossil evidence of this group is Early Cretaceous eggs of Ascarites spp. from a dinosaur coprolite in Belgium [101]. However, based on the earliest fossil record of their host group, an estimated date for the origin of ascarids would be in the Permian [15]. Ascarids radiated in numerous lines of vertebrates and invertebrates and have been recovered from more archaeological sites than any other human parasite. A selection of Pleistocene and Holocene sites containing the human ascarid, Ascaris 
TABLE 1: Records of the human stomach worm, Ascaris lumbricoides, from global archaeological sites.

\begin{tabular}{|c|c|c|c|}
\hline Country & Site & Date & Reference \\
\hline \multirow{5}{*}{ France } & Clairvaux, Jura & $3600 \mathrm{BC}$ & [149] \\
\hline & Chalain, Jura & $2700-2440 \mathrm{BC}$ & [149] \\
\hline & Bobigny & 2nd century AD & {$[175]$} \\
\hline & Paris & 14th-15th century AD & {$[176]$} \\
\hline & Marly-le-Roi, Yveline & 17th-18th century AD & {$[177]$} \\
\hline \multirow{3}{*}{ Germany } & Drobintz girl & $600 \mathrm{BC}$ & {$[178]$} \\
\hline & Bremerhaven & $100 \mathrm{BC}-500 \mathrm{AD}$ & {$[179]$} \\
\hline & Lübeck and other cities & 15 th century AD & {$[180]$} \\
\hline \multirow{10}{*}{ England } & Somerset & $4100-2600 \mathrm{BP}$ & {$[181]$} \\
\hline & Winchester & Roman period & {$[182]$} \\
\hline & Lindow Man & 2nd century AD & [183] \\
\hline & York & 2nd-3rd century AD & [184] \\
\hline & York & 9th-10th century AD & [185] \\
\hline & Winchester & 1000 years & {$[186]$} \\
\hline & Winchester & $1100 \mathrm{AD}$ & [187] \\
\hline & Southampton & 13th-14th century AD & {$[188]$} \\
\hline & York & 14th-16th century AD & [189] \\
\hline & Worcester & 15th century & {$[190]$} \\
\hline \multirow{5}{*}{ N. America } & Kentucky Salts Cave & $1125-290 \mathrm{BC}$ & {$[191]$} \\
\hline & Tennessee Big Bone Cave & $2177 \pm 145 \mathrm{BP}$ & {$[192]$} \\
\hline & Arizona Elden Pueblo & $1070-1250 \mathrm{AD}$ & [193] \\
\hline & Adak Island, Alaska & $840 \pm 40 \mathrm{BP}$ & {$[194]$} \\
\hline & Williamsburg, Virginia & $1720 \mathrm{AD}$ & {$[195]$} \\
\hline Africa & Kruger Cave, Rustenburg & $10,000-7,000 \mathrm{BP}$ & [196] \\
\hline \multirow{2}{*}{ Middle East } & Egypt PUM mummy & $200 \mathrm{BC}$ & {$[197]$} \\
\hline & Acre, Israel & 13 century AD & [198] \\
\hline \multirow{3}{*}{ S. America } & Huarmey Valley, Peru & $2277 \mathrm{BC} \pm 181$ & [199] \\
\hline & Gentio Cave, Brazil & $3490 \pm 120 \mathrm{BP}$ & [106] \\
\hline & Brazil sites & $8800-7000 \mathrm{BP}$ & [200] \\
\hline New Zealand & Wellington & $150-200$ years & {$[201]$} \\
\hline
\end{tabular}

lumbricoides, extending back 30,000 years [144] is presented in Table 1 and shows the geographical range of this parasite over various time periods. It has been suggested that humans acquired $A$. lumbricoides from pigs, since they harbour the closely related species, $A$. suum. However, A. lumbricoides has been recovered from Old World chimpanzees, gorillas, and bonobos as well as from New World howler monkeys [145147] and the original infections in humans were probably acquired from apes and simians.

Hookworms are another clade of nematode intestinal parasites recovered from archaeological finds and reports of these parasites have been recently summarized [106]. The two species attacking humans, Ancylostoma duodenale and Necator americanus, are usually lumped together since the stages normally recovered (eggs and first stage juveniles) are so similar that it is impossible to distinguish them by morphological methods. New World records date back to 7230 BP [148], while Old World records are slightly younger (3600 BP) [149]. Hookworms probably evolved from freeliving microbotrophic soil nematodes. Based on the earliest fossil record of their host group, an estimated date for the origin of hookworms would be in the Palaeocene [15]. Again, there is a good possibility that humans originally acquired infections from apes and simians since $N$. americanus has been found in chimpanzees [150] and $A$. duodenale infects Bonoboas [151] and Howler monkeys [146].

Another intestinal parasite that has been traced in archaeological remains is the human whipworm, Trichuris trichiura. Most findings are from the Old World, with the oldest record of 10,000-7,000 years BP coming from Africa [152], although eggs of this genus from rodent coprolites date back to 30,000 [153]. Reports of these have been recently summarized [106]. Based on the earliest fossil record of their host group, an estimated date for the origin of whipworms would be in the Carboniferous [15]. Whipworms infect a range of vertebrates, including dogs, cats, mice, pigs, and sheep. The presence of the human whipworm in Old World simians and primates [145, 147, 154-157] provides an avenue for human infections.

While parasites in the lumen of the alimentary track of vertebrates can be discovered in mummies and coprolites, the remains of insect vectored nematodes are usually not available in archaeological deposits unless molecular and 
immunological methods are used. Filarial nematodes adjacent to their insect vectors in Dominican amber establish the presence of filariids in the Cenozoic along with their blackfly and mosquito insect vectors [15]. Based on the earliest fossil record of their host group, an estimated date for the origin of filariids would be in the Carboniferous [15].

Fossil evidence of phytoparasitic nematodes is quite rare. The earliest record of plant parasitism by nematodes is the 400 mya Devonian parasite, Palaeonema phyticum, that was developing in the stomatal chambers of the Early Devonian (396 mya) land plant, Aglaophyton major. This species was an epistrate feeder that mechanically disrupted cortical cells and ingested the contents [158]. Palaeonema probably evolved from free-living microbotrophic clades that entered the natural opening of Aglaophyton to escape predators and explore a new food source. Lineages with this type of behavior are rare today since most plant parasites have evolved a stylet that is used to penetrate plant tissue and withdraw cell sap. Such stylet bearing nematodes are quite rare as fossils of higher plants and thus far are only represented by a population of Oligaphelenchoides maximis inside plant tissue in Dominican amber [15]. Their early lineages were probably free-living fungal feeders.

3.3. Trematodes. Trematodes or flukes can also be found in ancient human remains and reports of liver flukes, Fasciola hepatica, and schistosomes, Schistosoma spp., in archaeological sites have been recently summarized [106]. It is interesting that $F$. hepatica has only been recovered in Old World coprolites, in spite of its global occurrence today in cattle and sheep. Subfossils of both genera date back some 5,000 years $[159,160]$. It has been suggested that humans acquired schistosomes from ruminant and rodent definitive hosts sometime in the Miocene [161]. This is quite possible since the oldest fossil evidence of this group is an egg of the trematode, Digenites proterus, recovered from a dinosaur coprolite in the Early Cretaceous Bernissart Iguanodon shaft in Belgium [101].

3.4. Cestodes. Cestodes or tapeworms are another parasite group that occurs in coprolites. The oldest fossil records of this group are 270 million-year-old tapeworm eggs in a shark coprolite [162], which suggests that terrestrial tapeworms might have originated in a marine habitat. Archaeological finds usually reveal the three tapeworm species, Taeina saginata, T. asiatica, and T. solium that infect humans through cattle and pigs. There is evidence that these and probably other tapeworms were originally acquired when humans devoured wild bovids and swine before these animals were domesticated [163]. Early records of Taenia eggs in human mummies date back to $3200 \mathrm{BP}$ [164].

\section{Parasitic Arthropods}

While there are many examples of parasitic wasps in the fossil record, there are very few examples of actual parasitism. Some samples occur in amber and several of these show evidence of dryinid wasp parasitism of planthoppers [3]. Evidence of an early stage ichneumonid wasp larva that was dislodged from its feeding position on the abdomen of a spider appeared in Dominican amber [165]. Such larvae first feed on spider hemolymph from the outside and then eventually consume the organs of the spider. Other evidence of spider parasitism by wasps in Dominican amber is an ichneumonid wasp larva that devoured the eggs of a spider and then pupated adjacent to the adult spider [166].

Worker Formica ants are parasitized by small braconid wasps that deposit their eggs directly into the body cavity of the host. The parasitic larvae develop in the ant's hemocoel and when mature, emerge between the abdominal segments and form a cocoon for pupation in the soil [167]. Evidence that the ancestors of extant Elasmosoma wasps have been around for some 40 million years came from a braconid wasp larva emerging from a worker ant in Baltic amber [168].

Strepsiptera, a unique order of insects, have another method of parasitizing insects. They possess active first instar larvae called triungulins that search the environment for planthopper hosts. After finding and entering the body of a planthopper, the active triungulin molts into a sedimentary larva that develops to an adult inside the host. The winged adult males emerge and search for females that remain in their planthopper hosts with part of their body protruding for mating purposes. After fertilization the developing eggs hatch into a new generation of triungulins that swarm out of the female's brood pouch prepared to search for another victim. The oldest records of actual parasitism by this group are puparia inside an Eocene ant [169] and a female inside a Baltic amber ant [170]. A group of triungulins leaving their delphacid planthopper host was captured in Dominican amber when the infected planthopper landed in some resin [171]. An empty puparium in a halictid bee shows another host group for Tertiary strepsiptera [171].

A larval hymenopteran emerging from an adult trichopteran was found in Baltic amber [172]. This association is presently unknown, since today only the larval and pupal stages of trichopterans are parasitized by hymenopterans. Some tachinid fly parasitoids deposit eggs directly on their insect hosts and this behavior was noted in Dominican amber where the leaf beetle, Stenaspidiotus microptilus, had a tachinid egg attached to its pronotum [173].

Some interesting arthropod parasites were recently described from dog mummies in Egypt [174]. Numerous specimens of the dog tick, Rhipicephalus sanguineus, and a specimen of the louse fly, Hippobosca longipennis, were found still attached to the remains of dogs in tombs at the El Deir site in Egypt. While only dating to Roman times, they do show vector associations and suggest possible disease transmission scenarios.

\section{Discussion and Conclusions}

Tracing the history of diseases is similar to climbing the evolutionary scale, with free-living organisms at the base and a series of mutated parasitic stages appearing along the ascent until ultimately, human pathogens appear at the peak. The 
origins and coevolution of infectious agents are reflected in their present life histories and associations with their hosts. Whether the infection is latent or virulent, includes single or multiple hosts, is permanently associated with the host or has a resistant free-living stage, has both an intermediate as well as a definitive host, and is vector spread or a contagion are reflected in the evolutionary history of the infectious agent, which often extends back millions of years.

The evolutionary history of host-pathogen associations may also determine how long the relationships will continue under future fluctuating environmental and climatic conditions. It is often the least specialized associations that survive such changes. An example is the polydnaviruses that occur only in certain groups of parasitic wasps and probably date back to the early lineages of these wasps. While very successful now, their host specificity makes polydnaviruses especially vulnerable to extinction if conditions change. If a particular wasp lineage becomes extinct because its host is eradicated, the virus also disappears. In contrast, the iridoviruses infecting the sow bug have a wide host range, crossing phyla, and even infecting vertebrates. The origin of iridoviruses probably extends back to early invertebrate lineages and these viruses have a much better chance of survival since if one host group disappears, the infection continues in other hosts. The polyhedral viruses fall between polydnaviruses and iridoviruses in being restricted to more than one genus of insects but rarely crossing families and never crossing phyla. These viral groups survived the long period of coevolution with their hosts although others certainly became extinct along the way. Unfortunately very little is known about the evolution of pathogenic viruses in reservoir hosts and how long it took before the infection became latent or if it ever was virulent. Undetectable amounts of viruses certainly exist as latent infections in all vertebrates (reservoir hosts) and some of these eventually enter humans as highly virulent pathogens.

With pathogenic bacteria, a similar situation occurs between the infectious agent and the host. Several species of the genus Bacillus coevolved with insects and became overt pathogens. At least one, $B$. anthracis, became a vertebrate pathogen that also infects humans. The apparent absence of reservoir hosts and the persistence of the pathogen in the environment in the form of resting spores separate this group from most pathogenic forms such as plague bacteria and Lyme disease spirochetes. These traits suggest that Bacillus is in an early evolutionary stage with its hosts.

Fossil evidence of protozoan infections indicates that lineages of Leishmania evolved in their insect vectors long before they infected vertebrates. The pathway of infection was initiated through sand fly larvae feeding on flagellates in the environment. The presence of gametogenesis and syngamy of Plasmodium in a mosquito in Dominican amber indicates the vector as the original host. Another character used to determine the original host in arthropod-vector associations is the amount of damage done to both arthropod and vertebrate hosts. The host showing the least amount of damage is considered the primary host.

Parasitic helminthes obviously evolved from free-living ancestors but their origins are a mystery since no early progenitors have been found. An estimate of the date for their origins can be made from the earliest fossil record of their host group. As with the above pathogen groups, some lineages are associated with specific hosts and others with multiple hosts. An example of the former is nematodes of the genus Parasitodiplogaster that coevolved with fig wasps and are at risk of extinction if their host lineage perishes. In contrast, vertebrate parasitic nematodes of the genus Ascaris coevolved with a wide range of hosts and their existence is much more secure.

Based on our present knowledge and evidence from the past, it is obvious that both contagion and vector-borne pathogens are quite ancient. There is no definite subfossil evidence that any of these pathogens originated in humans. Humans acquired them from reservoir hosts (zoonosis) that had asymptomatic infections after a precarious balance was established with the pathogen [174]. Such a balance is absent when the pathogens are introduced into humans and then they become overt and highly virulent.

Unfortunately, we know very little about the development of human pathogens in reservoir hosts and arthropod vectors or why some vectors are more efficient carriers than others. All of these traits are connected with the coevolution of pathogens with their hosts that occurred millions of years ago.

The host-parasite associations around us today represent various stages of coevolution. Some may be at the end of their evolutionary line while others may be in the middle or just beginning. Most of these associations will be unsuccessful for one reason or another while others will survive and fall into one or more of the following recognized stages of symbiotic relationships: inquilinism (two organisms living in the same habitat), commensalism (one of the two organisms benefits), mutualism (both organisms benefit), or parasitism (one organism takes nourishment from the other, which suffers). Determining the intricacies of these evolutionary stages presents a challenge to future generations of scientists.

\section{Conflict of Interests}

The author declares that there is no conflict of interests regarding the publication of this paper.

\section{Acknowledgments}

The author thanks Roberta Poinar for discussions and comments on earlier drafts of this paper, T. N. Taylor for supplying Figure 61, Debi Poinar for supplying Figures 18 and 19, and Raymond Jacobson for supplying references and comments.

\section{References}

[1] G. O. Poinar Jr., "The origin of insect-borne human diseases as revealed in amber," The American Entomologist, vol. 57, no. 3, pp. 170-178, 2011.

[2] A. J. Boucot, Evolutionary Paleobiology of Behavior and Coevolution, Elsevier, New York, NY, USA, 1990.

[3] A. J. . Boucot and G. O. Poinar Jr., Fossil Behavior Compendium, CRC Press, Boca Raton, Fla, USA, 2010. 
[4] B. M. Rothschild and L. D. Martin, Paleopathology: Disease in the Fossil Record, CRC Press, Boca Raton, Fla, USA, 1993.

[5] C. M. Fauquet and D. Fargette, "International committee on taxonomy of viruses and the 3,142 unassigned species," Virology Journal, vol. 2, article 64, 2005.

[6] G. O. Poinar Jr. and R. Poinar, "Fossil evidence of insect pathogens," Journal of Invertebrate Pathology, vol. 89, no. 3, pp. 243250, 2005.

[7] R. T. Hess, G. S. Benham Jr., and G. O. Poinar Jr., "The ultrastructure of microorganisms in the tissues of Casinaria infesta (Cresson) (Hymenoptera: Ichneumonidae)," Journal of Invertebrate Pathology, vol. 26, no. 2, pp. 181-191, 1975.

[8] G. O. Poinar Jr., R. Hess, and L. E. Caltagirone, "Virus-like particles in the calyx of Phanerotoma flavitestacea (Hymenoptera: Braconidae) and their transfer into host tissues," Acta Zoologica, vol. 57, no. 3, pp. 161-165, 1976.

[9] A. Katzourakis, "Paleovirology: inferring viral evolution from host genome sequence data," Philosophical Transactions of the Royal Society B, vol. 368, no. 1626, Article ID 20120493, 2013.

[10] E. A. Herniou, E. Huguet, J. Thézé, A. Bézier, G. Periquet, and J. M. Drezen, "When parasitic wasps hijacked viruses: genomic and functional evolution of polydnaviruses," Philosophical Transactions of the Royal Society B, vol. 368, no. 1626, Article ID 20130051, 2013.

[11] R. T. Hess and G. O. Poinar Jr., "Iridoviruses infecting terrestrial isopods and nematodes," Current Topics in Microbiology and Immunology, vol. 116, pp. 49-76, 1985.

[12] H. B. Whittington, The Burgess Shale, Yale University Press, New Haven, Conn, USA, 1985.

[13] G. O. Poinar Jr., "Fossil flatus: indirect evidence of intestinal microbes," in Fossil Behavior Compendium, A. J. Boucot and G. O. Poinar Jr., Eds., pp. 22-25, CRC Press, Boca Raton, Fla, USA, 2010.

[14] S. M. Awramik, J. W. Schopf, and M. R. Walter, "Filamentous fossil bacteria from the Archean of Western Australia," Precambrian Research, vol. 20, no. 2-4, pp. 357-374, 1983.

[15] G. O. Poinar Jr., The Evolutionary History of Nematodes, Brill, Leiden, The Netherlands, 2011.

[16] G. O. Poinar Jr., "Spirochete-like cells in a Dominican amber Ambylomma tick (Arachnida: Ixodidae)," in Historical Biology: An International Journal of Paleobiology, pp. 1-6, 2014.

[17] D. E. Sonenshine, Biology of Ticks, vol. 2, Oxford University Press, Oxford, UK, 1993.

[18] G. O. Poinar Jr. and R. Poinar, The Amber Forest, Princeton University Press, Princeton, NJ, USA, 1999.

[19] A. Keller, A. Graefen, M. Ball et al., "New insights into the Tyrolean Iceman's origin and phenotype as inferred by wholegenome sequencing," Nature Communications, vol. 3, article 698, 2012.

[20] G. O. Poinar Jr. and A. E. Brown, "A new genus of hard ticks in Cretaceous Burmese amber (Acari: Ixodida: Ixodidae)," Systematic Parasitology, vol. 54, no. 3, pp. 199-205, 2003.

[21] G. O. Poinar Jr. and R. Buckley, "Compluriscutula vetulum (Acari: Ixodida: Ixodidae), a new genus and species of hard tick from Lower Cretaceous Burmese amber," Proceedings of the Entomological Society of Washington, vol. 110, no. 2, pp. 445-450, 2008.

[22] G. O. Poinar Jr. and G. M. Thomas, Diagnostic Manual for the Identification of Insect Pathogens, Plenum Press, New York, NY, USA, 1978.
[23] E. Weiss and J. W. Moulder, "Order rickettsiales gieszczkiewicz 1939," in Bergey's Manual of Systematic Bacteriology, N. R. Krieg and J. G. Holt, Eds., pp. 687-729, Williams and Wilkins, Baltimore, Md, USA, 1984.

[24] G. Blanc, "Comportement de Rickettsia barneti chez la tique, Hyalomma aegyptium (L.) sur la tortue terrestre, Testudo graeca," Pathologie et Microbiologie, vol. 24, pp. 21-26, 1961.

[25] G. O. Poinar Jr. and R. Poinar, What Bugged the Dinosaurs? Princeton University Press, Princeton, NJ, USA, 2008.

[26] M. J. Lehane, Biology of Blood-Sucking Insects, Harper Collins, London, UK, 1991.

[27] H. A. Lechevalier, "Nocardioforms", in Bergey's Manual of Systematic Bacteriology, N. R. Krieg and J. G. Holt, Eds., pp. 1458-1506, Williams \& Wilkins, Baltimore, Md, USA, 1984.

[28] G. O. Poinar Jr., “Triatoma dominicana sp. n. (Hemiptera: Reduviidae: Triatominae), and Trypanosoma antiquus sp. n. (Stercoraria: Trypanosomatidae), the first fossil evidence of a triatomine-trypanosomatid vector association," Vector-Borne and Zoonotic Diseases, vol. 5, no. 1, pp. 72-81, 2005.

[29] G. O. Poinar Jr., "Paleorhodococcus dominicanus n. gen., n sp. (Actinobacteria) in a faecal droplet of Triatoma dominicana (Hemiptera: Reduviidae: Triatominae) in Dominican amber," Historical Biology, vol. 24, no. 3, pp. 219-221, 2012.

[30] G. O. Poinar Jr., "Fossil nematodes from Mexican amber," Nematologica, vol. 23, no. 2, pp. 232-238, 1977.

[31] R. P. Dollfus, Parasites des Helminthes, Paul Lechevalier, Paris, France, 1946

[32] G. O. Poinar Jr., "Notes on the origins and evolution of Bacillus in relation to insect parasitism," in Fossil Behavior Compendium, A. J. Boucot and G. O. Poinar Jr., Eds., pp. 68-71, CRC Press, Boca Raton, Fla, USA, 2010.

[33] G. M. Garrity, J. A. Bell, and T. G. Lilburn, "Taxonomic outline of the Prokaryotes," in Bergey's Manual of Systematic Bacteriology, Springer, Heidelberg, Germany, 2nd edition, 2004.

[34] N. G. Gratz, "Rodents and human disease: a global appreciation," in Rodent Pest Management, I. Pakash, Ed., pp. 101-169, CRC Press, Boca Raton, Fla, USA, 1988.

[35] L. A. Durden and R. Traub, "Fleas (Siphonaptera)," in Medical and VeterInary Entomology, D. Mullen and L. A. Durden, Eds., pp. 103-145, Academic Press, Amsterdam, The Netherland, 2002.

[36] K. I. Bos, V. J. Schuenemann, G. B. Golding et al., "A draft genome of Yersinia pestis from victims of the Black Death," Nature, vol. 478, no. 7370, pp. 506-510, 2011.

[37] A. M. Devault, G. B. Golding, N. Waglechner et al., "Second pandemic strain of Vibrio cholerae from the Philadelphia cholera Outbreak of 1849," The New England Journal of Medicine, vol. 370, pp. 334-340, 2014.

[38] Ł. Fostowicz-Frelik and G. J. Frelik, "Earliest record of dental pathogen discovered in a North American eocene rabbit," Palaios, vol. 25, no. 12, pp. 818-822, 2010.

[39] G. O. Poinar Jr., "Palaeomyia burmitis (Diptera: Phlebotomidae), a new genus and species of Cretaceous sand flies with evidence of blood-sucking habits," Proceedings of the Entomological Society of Washington, vol. 106, pp. 598-605, 2004.

[40] G.O. Poinar Jr. and R. Poinar, "Paleoleishmania proterus n. gen., n. sp., (Trypanosomatidae: Kinetoplastida) from Cretaceous Burmese amber," Protist, vol. 155, no. 3, pp. 305-310, 2004.

[41] G. O. Poinar Jr. and R. Poinar, "Evidence of vector-borne disease of early cretaceous reptiles," Vector-Borne and Zoonotic Diseases, vol. 4, no. 4, pp. 281-284, 2004. 
[42] S. Kamhawi, "The journey of Leishmania parasites within the digestive tract of phlebotomine sand flies," in Leishmania, J. P. Farrell, Ed., pp. 59-73, Kluwer Academic, Dordrecht, Germany, 2002.

[43] J. R. Baker, "The evolution of parasitic protozoa," in Evolution of Parasites, A. E. R. Taylor, Ed., pp. 1-27, Blackwell Scientific, Oxford, UK, 1965.

[44] G. O. Poinar Jr., R. L. Jacobson, and C. L. Eisenberger, "Early cretaceous phlebotomine sand fly larvae (Diptera: Psychodidae)," Proceedings of the Entomological Society of Washington, vol. 108, no. 4, pp. 785-792, 2006.

[45] G. O. Poinar Jr. and A. E. Brown, "A non-gilled hymenomycete in Cretaceous amber," Mycological Research, vol. 107, no. 6, pp. 763-768, 2003.

[46] G. O. Poinar Jr., "Early Cretaceous trypanosomatids associated with fossil sand fly larvae in Burmese amber," Memorias do Instituto Oswaldo Cruz, vol. 102, no. 5, pp. 635-637, 2007.

[47] A. G. B. Simpson, J. R. Stevens, and J. Lukeš, "The evolution and diversity of kinetoplastid flagellates," Trends in Parasitology, vol. 22, no. 4, pp. 168-174, 2006.

[48] R. B. McGhee and W. B. Cosgrove, "Biology and physiology of the lower trypanosomatidae," Microbiological Reviews, vol. 44, no. 1, pp. 140-173, 1980.

[49] T. B. Clark, W. R. Kellen, J. E. Lindegren, and T. A. Smith, "The transmission of Crithidia fasiculata Leger 1902 in Culiseta incidens (Thomson)," Journal of protozoology, vol. 11, no. 3, pp. 400-402, 1964.

[50] P. Volf, A. Kiewegová, and A. Nemec, "Bacterial colonisation in the gut of Phlebotomus duboscqi (Diptera: Psychodidae): transtadial passage and the role of female diet," Folia Parasitologica, vol. 49, no. 1, pp. 73-77, 2002.

[51] E. A. Steinhaus, Principles of Insect Pathology, McGraw-Hill, New York, NY, USA, 1949.

[52] D. Azar, A. Nel, M. Solignac, J.-C. Paicheler, and F. Bouchet, "New genera and species of psychodoid flies from the Lower Cretaceous amber of Lebanon," Palaeontology, vol. 42, no. 6, pp. 1101-1136, 1999.

[53] J. A. Downs, "The ecology of blood-sucking Diptera: an evolutionary perspective," in Ecology and Physiology of Parasites, A. M. Fallis, Ed., pp. 232-258, University of Toronto Press, Toronto, Canada, 1970.

[54] J. D. Filho and R. P. Brazil, "Relationships of new world Phlebotomine sand flies (Diptera: Psychodidae) based on fossil evidence," Memórias do Instituto Oswaldo Cruz, vol. 98, 1, pp. 145-149, 2003.

[55] R. Lainson and J. J. Shaw, "Evolution, classification and geographical distribution," in The Leishmaniases in Biology and Medicine, W. Peters and R. Killick-Kendrick, Eds., vol. 1, pp. 1112, Academic Press, London, UK, 1987.

[56] S. F. Kerr, "Palaearctic Origin of Leishmania," Memórias do Instituto Oswaldo Cruz, vol. 95, no. 1-2, pp. 75-80, 2000.

[57] T. C. Orlando, M. A. T. Rubio, N. R. Sturm, D. A. Campbell, and L. M. Floeter-Winter, "Intergenic and external transcribed spacers of ribosomal RNA genes in lizard-infecting Leishmania: molecular structure and phylogenetic relationship to mammalinfecting Leishmania in the subgenus Leishmania (Leishmania)," Memórias do Instituto Oswaldo Cruz, vol. 97, no. 5, pp. 695-701, 2002.

[58] S. R. Telford Jr., "The kinetoplastid hemoflagellates of reptiles," in Parasitic Protozoa, J. P. Kreier, Ed., vol. 10, pp. 161-223, Academic Press, San Diego, Calif, USA, 2nd edition, 1995.
[59] V. C. L. C. Wilson and B. A. Southgate, "Lizard Leishmania," in Biology of the Kinetoplastida, W. H. R. Lumsden and D. A. Evans, Eds., vol. 2, pp. 241-268, Academic Press, London, UK, 1979.

[60] P. P. Perfilev, "Phlebotomidae (Sandflies)," in Diptera of the U.S.S.R., A. A. Strelkov, Ed., vol. 3, 2, pp. 1-363, Nauka, Moscow, Russia, 1966.

[61] D. J. Lewis, "Phlebotomidae and psychodidae (Sand-flies and Moth-flies)," in Insects and Other Arthropods of Medical Importance, K. G. V. Smith, Ed., pp. 155-179, The Trustees of the British Museum (Natural History), London, UK, 1973.

[62] S. F. Kerr, "Molecular trees of trypanosomes incongruent with fossil records of hosts," Memórias do Instituto Oswaldo Cruz, vol. 101, no. 1, pp. 25-30, 2006.

[63] H. A. Noyes, D. A. Morrison, M. L. Chance, and J. T. Ellis, "Evidence for a neotropical origin of Leishmania," Memórias do Instituto Oswaldo Cruz, vol. 95, no. 4, pp. 575-578, 2000.

[64] G. O. Poinar Jr., "Lutzomyia adiketis sp. n. (Diptera: Phlebotomidae), a vector of Paleoleishmania neotropicum sp. n. (Kinetoplastida: Trypanosomatidae) in Dominican amber," Parasites \& Vectors, vol. 1, article 22, 2008.

[65] L. L. Walters, G. B. Modi, R. B. Tesh, and T. Burrage, "Hostparasite relationship of Leishmania mexicana mexicana and Lutzomyia abonnenci (Diptera: Psychodidae)," The American Journal of Tropical Medicine and Hygiene, vol. 36, no. 2, pp. 294314, 1987.

[66] L. L. Walters, G. L. Chaplin, G. B. Modi, and R. B. Tesh, "Ultrastructural biology of Leishmania (Viannia) panamensis (=Leishmania Braziliensis panamensis) in Lutzomyia gomezi (Diptera: psychodidae): a natural host-parasite association," The American Journal of Tropical Medicine and Hygiene, vol. 40, no. 1, pp. 19-39, 1989.

[67] L. L. Walters, G. B. Modi, G. L. Chaplin, and R. B. Tesh, "Ultrastructural development of Leishmania chagasi in its vector, Lutzomyia longipalpis (Diptera: Psychodidae)," The American Journal of Tropical Medicine and Hygiene, vol. 41, no. 3, pp. 295317, 1989.

[68] G. O. Poinar Jr., "Leptoconops nosopheris sp. n. (Diptera: Ceratopogonidae) and Paleotrypanosoma burmanicus gen. n., sp. n. (Kinetoplastida: Trypanosomatidae), a biting midgetrypanosome vector association from the Early Cretaceous," Memórias do Instituto Oswaldo Cruz, vol. 103, no. 5, pp. 468471, 2008.

[69] G. Auezova, Z. Brushko, and R. Kubykin, "Feeding of biting midges (Leptoconopidae) on reptiles," in Proceeding of the 2nd International Congress of Dipterology, p. 12, Bratislava, Czechoslovakia, September 1990.

[70] B. A. Mullens, C. Barrows, and A. Borkent, "Lizard feeding by Leptoconops (Brachyconops) californiensis (Diptera: Ceratopogonidae) on desert sand dunes," Journal of Medical Entomology, vol. 34, no. 6, pp. 735-737, 1997.

[71] A. P. Fernandes, K. Nelson, and S. M. Beverley, "Evolution of nuclear ribosomal RNAs in kinetoplastid protozoa: perspectives on the age and origins of parasitism," Proceedings of the National Academy of Sciences of the United States of America, vol. 90, no. 24, pp. 11608-11612, 1993.

[72] G. O. Poinar Jr. and R. Milki, Lebanese Amber, Oregon State University Press, Corvallis, Ore, USA, 2001.

[73] C. Hoare, The Trypanosomes of Mammals, Blackwell Scientific Publications, Oxford, UK, 1972.

[74] H. Lent and P. Wygodzinsky, "Revision of the Triatominae (Hemiptera, Reduviidae), and their significance as vectors of 
chagas' disease," Bulletin of the American Museum of Natural History, vol. 163, pp. 123-520, 1979.

[75] R. E. Ryckman, "The vertebrate hosts of the Triatominae of North and Central America and the West Indies (Hemiptera: Reduviidae: Triatominae)," Bulletin of the Society of Vector Ecology, vol. 11, pp. 221-241, 1986.

[76] F. Guhl, C. Jaramillo, R. Yockteng, G. A. Vallejo, and F. Cárdenas-Arroyo, "Trypanosoma cruzi DNA in human mummies,” The Lancet, vol. 349, no. 9062, p. 1370, 1997.

[77] G. O. Poinar Jr., "Panstrongylus hispaniolae sp. n. (Hemiptera: Reduviidae: Triatominae), a new fossil triatome in Dominican amber with evidence of gut flagellates," Palaeodiversity, vol. 6, pp. 1-8, 2013.

[78] J. A. Cerisola, C. E. del Prado, R. Rohwedder, and J. P. Bozzini, "Blastocrithidia triatomae n. sp. found in Triatoma infestans from Argentina," Journal of Protozoology, vol. 18, no. 3, pp. 503506, 1971.

[79] G. A. Schaub, "Pathogenicity of trypanosomatids on insects," Parasitology Today, vol. 10, no. 12, pp. 463-468, 1994.

[80] G. O. Poinar Jr. and S. R. Telford Jr., "Paleohaemoproteus burmacis gen. n., sp. n. (Haemospororida: Plasmodiidae) from an Early Cretaceous biting midge (Diptera: Ceratopogonidae)," Parasitology, vol. 131, no. 1, pp. 79-84, 2005.

[81] A. Borkent, Biting Midges in the Cretaceous Amber of North America (Diptera: Ceratopogonidae), Backhuys, Leiden, The Netherlands, 1995.

[82] S. S. Desser and G. F. Bennett, "The genera Leucocytozoon, Haemoproteus, and Hepatocystis," in Parasitic Protozoa, J. P. Kreier and J. R. Baker, Eds., vol. 4, pp. 273-307, Academic Press, San Diego, Calif, USA, 2nd edition, 1993.

[83] P. C. C. Garnham, Malaria Parasites and other Haemosporidia, Blackwell Scientific Publications, Oxford, UK, 1966.

[84] C. T. Atkinson and C. van Riper III, "Pathogenicity and epizootiology of avian Haematozoa: Plasmodium, Leucocytoozoon, and Haemoproteus," in Bird-Parasite Interactions: Ecology, Evolution, and Behaviour, J. E. Loye and M. Zuk, Eds., pp. 19-48, Oxford University Press, New York, NY, USA, 1991.

[85] G. F. Bennett and M. A. Peirce, "Morphological form in the avian Haemoproteidae and an annotated checklist of the genus Haemoproteus Kruse, 1890," Journal of Natural History, vol. 22, no. 6, pp. 1683-1696, 1988.

[86] A. M. Fallis and D. M. Wood, "Biting midges (Diptera: Ceratopogonidae) as intermediate hosts for Haemoproteus of ducks," Canadian Journal of Zoology, vol. 35, no. 3, pp. 425-435, 1957.

[87] S. R. Telford Jr., "Haemoparasites of reptiles," in Diseases of Amphibians and Reptiles, G. L. Hoff, F. L. Frye, and E. R. Jacobson, Eds., pp. 385-517, Plenum Press, New York, NY, USA, 1984.

[88] J. R. Linley, "Biting midges (Diptera: Ceratopogonidae) as vectors of nonviral animal pathogens," Journal of Medical Entomology, vol. 22, no. 6, pp. 589-599, 1985.

[89] G. O. Poinar Jr., “Culex malariager, n. sp. (Diptera: Culicidae) from Dominican amber: the first fossil mosquito vector of Plasmodium," Proceedings of the Entomological Society of Washington, vol. 107, no. 3, pp. 548-553, 2005.

[90] G. O. Poinar Jr., "Plasmodium dominicana n. sp. (Plasmodiidae: Haemospororida) from Tertiary Dominican amber," Systematic Parasitology, vol. 61, no. 1, pp. 47-52, 2005.

[91] J. C. Kissinger, P. C. A. Souza, C. O. Soares et al., "Molecular phylogenetic analysis of the avian malarial parasite Plasmodium (Novyella) juxtanucleare," Journal of Parasitology, vol. 88, no. 4, pp. 769-773, 2002.
[92] G. O. Poinar Jr., T. J. Zavortink, T. Pike, and P. A. Johnston, "Paleoculicis minutus (Diptera: Culicidae) n. gen., n. sp., from Cretaceous Canadian amber, with a summary of described fossil mosquitoes," Acta Geologica Hispanica, vol. 35, no. 1-2, pp. 119$128,2000$.

[93] A. P. Waters, D. G. Higgins, and T. F. McCutchan, "Plasmodium falciparum appears to have arisen as a result of lateral transfer between avian and human hosts," Proceedings of the National Academy of Sciences of the United States of America, vol. 88, no. 8, pp. 3140-3144, 1991.

[94] R. B. McGhee, "The adaptation of the avian malaria parasite Plasmodium lophurae to a continuous existence in infant mice," Journal of Infectious Diseases, vol. 88, no. 1, pp. 86-97, 1951.

[95] T. J. Zavortink and G. O. Poinar Jr., “Anopheles (Nyssorhynchus) dominicanus sp. n. (Diptera: Culicidae) from Dominican amber," Annals of the Entomological Society of America, vol. 93, no. 6, pp. 1230-1235, 2000.

[96] N. Cerutti, A. Marin, E. R. Massa, and D. Savoia, "Immunological investigation of malaria and new perspectives in paleopathological studies," Bollettino della Società Italiana di Biologia Sperimentale, vol. 75, no. 3-4, pp. 17-20, 1999.

[97] R. L. Miller, S. Ikram, G. J. Armelagos et al., "Diagnosis of Plasmodium falciparum infections in mummies using the rapid manual ParaSight(TM)-F test," Transactions of the Royal Society of Tropical Medicine and Hygiene, vol. 88, no. 1, pp. 31-32, 1994.

[98] G. O. Poinar Jr. and A. Brown, "The first fossil streblid bat fly, Enischnomyia stegosoma n. g., n. sp. (Diptera: Hippoboscoidea: Streblidae)," Systematic Parasitology, vol. 81, no. 2, pp. 79-86, 2012.

[99] G. O. Poinar Jr., "Vetufebrus ovatus n. gen., n. sp. (Haemospororida: Plasmodiidae) vectored by a streblid bat fly (Diptera: Streblidae) in Dominican amber," Parasites and Vectors, vol. 4, article 229, 2011.

[100] I. F. Keymer, "Protozoa," in Diseases of the Reptilia, J. E. Cooper and O. F. Jackson, Eds., vol. 1, pp. 233-290, Academic Press, London, UK, 1981.

[101] G. O. Poinar Jr. and A. J. Boucot, "Evidence of intestinal parasites of dinosaurs," Parasitology, vol. 133, no. 2, pp. 245-249, 2006.

[102] W. Frank, "Non-hemoparasitic protozoans," in Diseases of Amphibians and Reptiles, G. L. Hoff, F. L. Frye, and E. R. Jacobson, Eds., pp. 259-384, Plenum Press, New York, NY, USA, 1984.

[103] R. R. Kudo, Protozoology, Charles Thomas, Springfield, Ill, USA, 1954.

[104] F. L. Frye, Biomedical and Surgical Aspects of Captive Reptile Husbandry, Krieger, Malabar, Fla, USA, 2nd edition, 1991.

[105] M. L. Goncalves, V. L. da Silva, C. M. de Andrade et al., "Amoebiasis distribution in the past: first steps using an immunoassay technique," Transactions of the Royal Society of Tropical Medicine and Hygiene, vol. 98, no. 2, pp. 88-91, 2004.

[106] M. L. C. Gonçalves, A. Araújo, and L. F. Ferreira, "Human intestinal parasites in the past: new findings and a review," Memórias do Instituto Oswaldo Cruz, vol. 98, no. 1, pp. 103-118, 2003.

[107] I. Desportes and J. Schrevel, Treatise on Zoology-Anatomy, Taxonomy, Biology: The Gregarines: The Early Branching Apicomplexa, vol. 1, 2013.

[108] I. Desportes and J. Schrevel, Treatise on Zoology-Anatomy, Taxonomy, Biology: The Gregarines: The Early Branching Apicomplexa, vol. 2, 2013. 
[109] G. O. Poinar Jr. and G. M. Thomas, Laboratory Guide to Insect Pathogens and Parasites, Plenum Press, New York, NY, USA, 1984.

[110] G. O. Poinar Jr., "Primigregarina burmanica n. gen., n. sp., an early cretaceous gregarine (Apicomplexa: Eugregarinorida) parasite of a cockroach (Insecta: Blattodea)," in Fossil Behavior Compendium, A. J. Boucot and G. O. Poinar Jr., Eds., pp. 54-56, CRC Press, Boca Raton, Fla, USA, 2010.

[111] G. Poinar Jr., "Fossil gregarines in Dominican and Burmese amber: examples of accelerated development?" Palaeodiversity, vol. 5, pp. 1-6, 2013.

[112] G.-H. Sung, G. O. Poinar Jr., and J. W. Spatafora, “The oldest fossil evidence of animal parasitism by fungi supports a Cretaceous diversification of fungal-arthropod symbioses," Molecular Phylogenetics and Evolution, vol. 49, no. 2, pp. 495-502, 2008.

[113] G. O. Poinar Jr. and G. M. Thomas, "An entomophthoralen fungus from Dominican amber," Mycologia, vol. 74, pp. 332-334, 1982.

[114] G. O. Poinar Jr. and G. M. Thomas, "A fossil entomogenous fungus from Dominican amber," Experientia, vol. 40, no. 6, pp. 578-579, 1984.

[115] H.-B. Jansson and G. O. Poinar Jr., "Some possible fossil nematophagous fungi," Transactions of the British Mycological Society, vol. 87, no. 3, pp. 471-474, 1986.

[116] W. Morrow, "Holocene coccidioidomycosis: valley fever in early Holocene bison (Bison antiquus)," Mycologia, vol. 98, no. 5, pp. 669-677, 2006.

[117] W. R. Harrison, C. F. Merbs, and C. R. Leathers, "Evidence of coccidioidomycosis in the skeleton of an ancient Arizona Indian," Journal of Infectious Diseases, vol. 164, no. 2, pp. 436437, 1991.

[118] M. Sherwood-Pike, "Fossil evidence for fungus-plant interactions," in Evolutionary Paleobiology of Behavior and Coevolution, A. J. Boucot, Ed., pp. 118-123, Elsevier, Amsterdam, The Netherlands, 1990.

[119] T. N. Taylor and E. L. Taylor, The Biology and Evolution of Fossil Plants, Prentice Hall, Englewood Cliffs, NJ, USA, 1993.

[120] D. Redecker, R. Kodner, and L. E. Graham, "Glomalean fungi from the Ordovician," Science, vol. 289, no. 5486, pp. 1920-1921, 2000.

[121] T. N. Taylor, H. Hass, and W. Remy, "Devonian fungi: interactions with the green alga Palaeonitella," Mycologia, vol. 84, no. 6, pp. 901-910, 1992.

[122] H. Hass, T. N. Taylor, and W. Remy, "Fungi from the lower Devonian Rhynie chert: mycoparasitism," The American Journal of Botany, vol. 81, no. 1, pp. 29-37, 1994.

[123] G. O. Poinar Jr. and R. Buckley, "Evidence of mycoparasitism and hypermycoparasitism in Early Cretaceous amber," Mycological Research, vol. 111, no. 4, pp. 503-506, 2007.

[124] T. N. Taylor, H. Hass, H. Kerp, M. Krings, and R. T. Hanlin, "Perithecial ascomycetes from the 400 million year old Rhynie chert: an example of ancestral polymorphism," Mycologia, vol. 97, no. 1, pp. 269-285, 2005.

[125] R. S. Currah and R. A. Stockey, "A fossil smut fungus from the anthers of an Eocene angiosperm," Nature, vol. 350, no. 6320, pp. 698-699, 1991.

[126] Z.-Q. Wang, "Permian Supaia fronds and an associated Autunia fructification from Shanxi, China," Palaeontology, vol. 40, pp. 245-277, 1997.

[127] G. O. Poinar Jr., "Coelomycetes in Dominican and Mexican amber," Mycological Research, vol. 107, no. 1, pp. 117-122, 2003.
[128] G. O. Poinar Jr. and R. Buckley, "Nematode (Nematoda: Mermithidae) and hairworm (Nematomorpha: Chordodidae) parasites in Early Cretaceous amber," Journal of Invertebrate Pathology, vol. 93, no. 1, pp. 36-41, 2006.

[129] G. O. Poinar Jr., "Paleochordodes protus n.g., n.sp. (Nematomorpha, Chordodidae), parasites of a fossil cockroach, with a critical examination of other fossil hairworms and helminths of extant cockroaches (Insecta: Blattaria)," Invertebrate Biology, vol. 118, no. 2, pp. 109-115, 1999.

[130] S. Namnjou, M. Pedram, G. O. Poinar Jr., E. Pourjam, and M. R. Atighi, "Novel host associations for dorylaim nematodes (Nematoda: Dorylaimida)," International Journal of Nematology, vol. 23, pp. 104-107, 2013.

[131] G. O. Poinar Jr., A. Acra, and F. Acra, "Animal-animal parasitism in Lebanese amber," Medical Science Review, vol. 22, no. 2, article 159, 1994.

[132] G. O. Poinar Jr., "New fossil nematodes in Dominican and Baltic amber," Nematology, vol. 14, no. 4, pp. 483-488, 2012.

[133] G. O. Poinar Jr., "The mycetophagous and entomophagous stages of Iotonchium californicum n.sp. (Iotonchiidae: Tylenchida)," Revue de Nématologie, vol. 14, no. 4, pp. 565-580, 1991.

[134] G. O. Poinar Jr., “Taxonomy and biology of Steinernematidae and Heterorhabditidae," in Entomopathogenic Nematodes in Biological Control, R. Gaugler and H. K. Kaya, Eds., pp. 23-61, CRC Press, Boca Raton, Fla, USA, 1990.

[135] V. B. Dubinin, "The presence of Pleistocene lice (Anoplura) and nematodes in the cadaver of a fossilised gopher," Doklady Akademii Nauk SSSR, vol. 62, pp. 417-420, 1948.

[136] A. J. G. Araújo, U. E. C. Confalonieri, and L. F. Ferreira, "Oxyurid (Nematoda) egg from coprolites from Brazil," Journal of Parasitology, vol. 68, no. 3, pp. 511-512, 1982.

[137] G. D. Schmidt, D. W. Duszynski, and P. S. Martin, "Parasites of the extinct shasta ground sloth, Northotheriops shastensis, in Rampart Cave, Arizona," Journal of Parasitology, vol. 78, no. 5, pp. 811-816, 1992.

[138] G. F. Fry and J. G. Moore, "Enterobius vermicularis: 10,000-yearold human infection,” Science, vol. 166, no. 3913, p. 1620, 1969.

[139] A. M. Iñiguez, K. Reinhard, M. L. Carvalho Gonçalves, L. F. Ferreira, A. Araújo, and A. C. P. Vicente, "SL1 RNA gene recovery from Enterobius vermicularis ancient DNA in pre-Columbian human coprolites," International Journal for Parasitology, vol. 36, no. 13, pp. 1419-1425, 2006.

[140] O. Wei, "Internal organs of a 2100-year-old female corpse," The Lancet, vol. 2, no. 7839, p. 1198, 1973.

[141] P. D. Horne, "First evidence of enterobiasis in ancient Egypt," Journal of Parasitology, vol. 88, no. 5, pp. 1019-1021, 2002.

[142] H. Hasegawa, "Methods of collection and identification of minute nematodes from the feces of primates, with special application to coevolutionary studes of pinworms," in Primate Parasite Ecology, the Dynamics and Study of Host-Parasite Relationships, M. A. Huffman and C. A. Chapman, Eds., pp. 2946, Cambridge University Press, Cambridge, UK, 2009.

[143] M. M. Kliks, "Helminths as heirlooms and souvenirs: a review of New World paleoparasitology," Parasitology Today, vol. 6, no. 4, pp. 93-100, 1990.

[144] F. Bouchet, D. Baffier, M. Girard, P. Morel, J. C. Paicheler, and F. David, "Paléoparasitologie en contexte Pléistocène premières observations á la Grand Grotte d'Arcy-sur-Cure (Yonne), France," Compte Rendu Academie Science Paris, vol. 319, pp. 147151, 1996. 
[145] D. Fossey, Gorillas in the Mist, Houghton Mifflin Company, Boston, Mass, USA, 1983.

[146] M. Stuart, V. Pendergast, S. Rumfelt et al., "Parasites of wild howlers (Alouatta spp.)," International Journal of Primatology, vol. 19, no. 3, pp. 493-512, 1998.

[147] J. Dupain, C. Nell, K. J. Petrzelková, P. Garcia, D. Modry, and F. P. Gordo, "Gastrointestinal parasites of bonobos in the Lomako Forest, Democratic Republic of Congo," in Primate Parasite Ecology, the Dynamics and Study of Host-Parasite Relationships, M. A. Huffman and C. A. Chapman, Eds., pp. 297-310, Cambridge University Press, Cambridge, UK, 2009.

[148] L. F. Ferreira, A. Araújo, U. Confalonieri, and C. M. R. Filho, "The finding of hookworm eggs in human coprolites from $7230 \pm 80$ years BP, from Piauí, Brasil," Anais da Academia Brasileira de Ciencias, vol. 59, pp. 280-281, 1987.

[149] S. Dommelier-Espejo, Contribution à l'étude Paléoparasitologique des sites Néolithique en environment Lacustre dans les Domaines Jurassien et Péri-alpin" [Ph.D. Dissertationz], University de Reims, Reims, France, 2001.

[150] M. A. Huffman, P. Pebsworth, C. Bakuneeta, S. Gotoh, and M. Bardi, "Chimpanzee-parasite ecology at Budongo Forest (Uganda) and the Mahale Mountains (Tanzania): influence of climatic differences on self-medicative behaviour," in Primate Parasite Ecology, the Dynamics and Study of Host-Parasite Relationships, M. A. Huffman and C. A. Chapman, Eds., pp. 331350, Cambridge University Press, Cambridge, UK, 2009.

[151] B. de Thoisy, I. Vogel, J.-M. Reynes et al., "Health evaluation of translocated free-ranging primates in French Guiana," The American Journal of Primatology, vol. 54, no. 1, pp. 1-16, 2001.

[152] A. C. Evans, M. B. Markus, R. J. Mason, and R. Steel, "Late stoneage coprolite reveals evidence of prehistoric parasitism," South African Medical Journal, vol. 86, pp. 274-275, 1996.

[153] L. F. Ferreira, A. Araujo, U. Confalonieri, M. Chame, and D. C. Gomes, "Trichuris eggs in animal coprolites dated from 30,000 years ago," Journal of Parasitology, vol. 77, no. 3, pp. 491-493, 1991.

[154] C. A. Chapman, J. M. Rothman, and S. A. M. Hodder, "Can parasite infections be a selective force influencing primate group size? A test with red colobus," in Primate Parasite Ecology, the Dynamics and Study of Host-Parasite Relationships, M. A. Huffman and C. A. Chapman, Eds., pp. 423-440, Cambridge University Press, Cambridge, UK, 2009.

[155] A. Hernandez, A. J. Macintosh, and M. A. Huffman, "Primate parasite ecology: patterns and predictions from an ongoing study of Japanese macaques," in Primate Parasite Ecology, the Dynamics and Study of Host-Parasite Relationships, M. A. Huffman and C. A. Chapman, Eds., pp. 387-410, Cambridge University Press, Cambridge, UK, 2009.

[156] H. K. Ooi, F. Tenora, K. Itoh, and M. Kamiya, "Comparative study of Trichuris trichiura from non-human primates and from man, and their difference with T. suis," Journal of Veterinary Medical Science, vol. 55, no. 3, pp. 363-366, 1993.

[157] G. H. Liu, R. B. Gasser, P. Nejsum et al., "Mitochondrial and nuclear ribosomal DNA evidence supports the existence of a new Trichuris species in the endangered François'leaf-monkey," PLoS ONE, vol. 8, no. 6, 2103.

[158] G. O. Poinar Jr., H. Kerp, and H. Hass, "Palaeonema phyticum gen. n., sp. n. (Nematoda: Palaeonematidae fam. n.), a Devonian nematode associated with early land plants," Nematology, vol. 10, no. 1, pp. 9-14, 2008.

[159] S. Dommelier-Espejo, Contribuition à L'étude Paléoparasitologique des Sites Néolithiques en Environnement Lacustre dans les Domaines Jurassienet Péri-alpin, [Ph.D. thesis], Université de Reims, Reims, France, 2001.

[160] A. M. Deelder, R. L. Miller, N. de Jonge, and F. W. Krijger, "Detection of schistosome antigen in mummies," The Lancet, vol. 335, no. 8691, pp. 724-725, 1990.

[161] L. Despres, D. Imbert-Establet, C. Combes, and F. Bonhomme, "Molecular evidence linking hominid evolution to recent radiation of schistosomes (Platyhelminthes: Trematoda)," Molecular Phylogenetics and Evolution, vol. 1, no. 4, pp. 295-304, 1992.

[162] P. C. Dentzien-Dias, G. O. Poinar Jr., A. E. Q. de Figueiredo, A. C. L. Pacheco, B. L. D. Horn, and C. L. Schultz, "Tapeworm eggs in a 270 million-year-old shark coprolite," PLoS ONE, vol. 8, no. 1, Article ID e55007, 2013.

[163] E. P. Hoberg, N. L. Alkire, A. de Queiroz, and A. Jones, "Out of Africa: origins of the Taenia tapeworms in humans," Proceedings of the Royal Society of London B: Biological Sciences, vol. 268, no. 1469, pp. 781-787, 2001.

[164] T. A. Reyman, M. R. Zimmerman, and P. K. Lewin, "Autopsy of an Egyptian mummy (Nakht-ROM I)): histopathologic investigation," Canadian Medical Association Journal, vol. 117, no. 5, pp. 461-476, 1977.

[165] G. O. Poinar Jr., "Fossil evidence of spider parasitism by Ichneumonidae," Journal of Arachnology, vol. 14, no. 3, pp. 399-400, 1987.

[166] G. O. Poinar Jr., "Fossil evidence of spider egg parasitism by ichneumonid wasps," in Fossil Spiders in Amber and Copal, J. Wunderlich, Ed., vol. 3, pp. 1874-1877, Beiträge zur Araneologie, 2004.

[167] G. O. Poinar Jr., "Behaviour and development of Elasmosoma sp. (Neoneurinae: Braconidae: Hymenoptera), an endoparasite of Formica ants (Formicidae: Hymenoptera)," Parasitology, vol. 128, no. 5, pp. 521-531, 2004.

[168] G. O. Poinar Jr. and J. C. Miller, "First fossil record of endoparasitism of adult ants (Formicidaes: Hymenoptera) by Braconidae (Hymenoptera)," Annals of the Entomological Society of America, vol. 95, no. 1, pp. 41-43, 2002.

[169] H. Lutz, "Giant ants and other rarities: the insect fauna," in Messel, an Insight Into the History of Life and of the Earth, S. Schaal and W. Ziegler, Eds., pp. 55-67, Clarendon Press, Oxford, UK, 1992.

[170] H. Pohl and R. Kinzelbach, "First record of a female stylopid (Strepsiptera: ?Myrmecolacidae) parasite of a prionomyrmecine ant (Hymenoptera: Formicidae) in Baltic amber," Insect Systematics and Evolution, vol. 32, no. 2, pp. 143-146, 2001.

[171] G. Poinar, "Evidence of parasitism by Strepsiptera in Dominican amber," BioControl, vol. 49, no. 3, pp. 239-244, 2004.

[172] G. O. Poinar Jr. and N. H. Anderson, "Hymenopteran parasites of Trichoptera: the first fossil record," in Proceedings of the 11th International Symposium on Trichoptera, Osaka, pp. 343-346, Tokai University Press, Tokyo, Japan, 2003.

[173] G. O. Poinar Jr., "Stenaspidiotus microptilus n. gen., n. sp. (Coleoptera: Chrysomelidae: Chrysomelinae) in Dominican amber, with evidence of tachinid (Diptera: Tachinidae) oviposition," Historical Biology, vol. 25, no. 1, pp. 101-105, 2013.

[174] H. Krauss, A. Weber, M. Appel et al., Zoonoses: Infectious Diseases Transmissible from Animals to Humans, The American Society for Microbiology Press, Washington, DC, USA, 3rd edition, 2004.

[175] J. J. Rousset, C. Heron, and P. Metrot, "Human helminthiasis at the Gauls," Histoire des Sciences Medicales, vol. 30, no. 1, pp. 4146, 1996. 
[176] F. Bouchet, "Recovery of helminth eggs from archeological excavations of the Grand Louvre (Paris, France)," Journal of Parasitology, vol. 81, no. 5, pp. 785-787, 1995.

[177] F. Bouchet, S. Bentrad, and J. C. Paicheler, "Enquête épidémiologique sur les helminthiases à la cour de Louis XIV", MiniSynthese Medical Science, vol. 14, no. 4, pp. 463-466, 1998.

[178] L. Szidat, "Über die erhaltungsfähigkeit von helmintheneiern in Vor- und Frühgeschichtlichen moorleichen," Zeitschrift für Parasitenkunde, vol. 13, no. 3, pp. 265-274, 1944.

[179] J. Jansen Jr. and H. J. Over, "Het voorkomen van parasieten in terpmateriaal uit Noordwest Duitsland," Tijdschrift voor Diergeneeskunde, vol. 87, pp. 1377-1379, 1962.

[180] B. Herrmann, "Parasitologisch-epidemiologische auswertungen mittelalterlicher kloaken," Zeitschrift für Archäologie des Mittelalters, vol. 13, pp. 131-161, 1985.

[181] A. K. Jones and C. Nicholson, "Recent finds of Trichuris and Ascaris ova from Britain," Paleopathology Newsletter, no. 62, pp. 5-6, 1988.

[182] A. W. Pike, "Recovery of helminth eggs from archaeological excavations, and their possible usefulness in providing evidence for the purpose of an occupation," Nature, vol. 219, no. 5151, pp. 303-304, 1968.

[183] A. K. G. Jones, "Parasitological investigations on Lindow Man," in Lindow Man: The Body in the Bog, I. M. Stead, J. B. Bourke, and D. Brothwell, Eds., pp. 136-139, British Museum Publications, London, UK, 1986.

[184] A. Wilson and D. J. Rackham, "Parasite eggs," in The Archaeology of York: The Past Environment of York, the Environment Evidence from the Church Street Sewer System, pp. 32-33, Council for British Archaeology, York, UK, 1976.

[185] A. K. G. Jones, "Recent finds of intestinal parasite ova at York, England," in Proceeding of the 4th European Members Meeting on Paleopathology, p. 7, Antwerpen, Belgium, 1982.

[186] A. W. Pike, "The recovery of parasite eggs from ancient cesspit and latrine deposits: an approach to the study of early parasite infections," in Diseases in Antiquity, D. Brothwell and A. T. Sandison, Eds., pp. 184-188, Charles C Thomas, Springfield, Mass, USA, 1967.

[187] E. L. Taylor, "Parasitic helminths in medieval remains," Veterinary Record, vol. 67, pp. 218-228, 1955.

[188] A. W. Pike, "Parasite eggs," in Excavations in Medieval Southampton, C. Platt and R. Coleman-Smith, Eds., pp. 347-348, Leicester University Press, Leicester, UK, 1975.

[189] A. K. Jones and C. Nicholson, "Recent finds of Trichuris and Ascaris ova from Britain," Paleopathology News, no. 62, pp. 5-6, 1988.

[190] D. P. Moore, "Life seen from a medieval latrine," Nature, vol. 294, no. 5842, p. 614, 1981.

[191] G. F. Fry, "Apud reinhard KJ 1990, archaeoparasitology in North America," The American Journal of Physical Anthropology, vol. 82, no. 2, pp. 145-163, 1974.

[192] C. T. Faulkner, S. Patton, and S. S. Johnson, "Prehistoric parasitism in Tennessee: evidence from the analysis of desiccated fecal material collected from big bone cave, van buren county, tennessee," Journal of Parasitology, vol. 75, no. 3, pp. 461-463, 1989.

[193] R. H. Hevly, R. E. Kelly, G. A. Anderson, and S. J. Olsen, "Apud Reinhard KJ 1990, archaeoparasitology in North America," The American Journal of Physical Anthropology, vol. 82, pp. 145-163, 1979.
[194] F. Bouchet, D. West, C. Lefèvre, and D. Corbett, "Identification of parasitoses in a child burial from Adak Island, (Central Aleutian Island, Alaska)," Comptes Rendus de l'Académie des Sciences-Series III-Sciences de la Vie, vol. 324, no. 2, pp. 123 127, 2001.

[195] K. J. Reinhard, "Archaeparasitology in North America," The American Journal of Physical Anthropology, vol. 82, no. 2, pp. 145-163, 1990.

[196] A. C. Evans, M. B. Markus, R. J. Mason, and R. Steel, "Late stone age coprolite reveals evidence of prehistoric parasitism," South African Medical Journal, vol. 86, pp. 274-275, 1996.

[197] A. Cockburn, R. A. Barraco, T. A. Reyman, and W. H. Peck, "Autopsy of an Egyptian mummy," Science, vol. 187, no. 4182, pp. 1155-1160, 1975.

[198] P. D. Mitchell and E. Stern, "Parasitic intestinal helminth ova from the latrines of the 13th century crusader hospital of St. John in Acre, Israel," in Proceeding of the 13th Biennial European Members Meeting of the Paleopathology Association, pp. 21-22, Chieti, Italy, 2000.

[199] R. Patrucco, R. Tello, and D. Bonavia, "Parasitological studies of coprolites of pre-hispanic Peruvian populations," Current Anthropology, vol. 24, pp. 393-394, 1983.

[200] D. Leles, A. Araújo, L. F. Ferreira, A. C. P. Vicente, and A. M. Iñiguez, "Molecular paleoparasitological diagnosis of Ascaris sp. from coprolites: new scenery of ascariasis in pre-Columbian South America times," Memórias do Instituto Oswaldo Cruz, vol. 103, no. 1, pp. 106-108, 2008.

[201] J. R. Andrews, “Ascaris egg in coprolite material," New Zealand Medical Journal, vol. 89, no. 633, p. 274, 1979. 

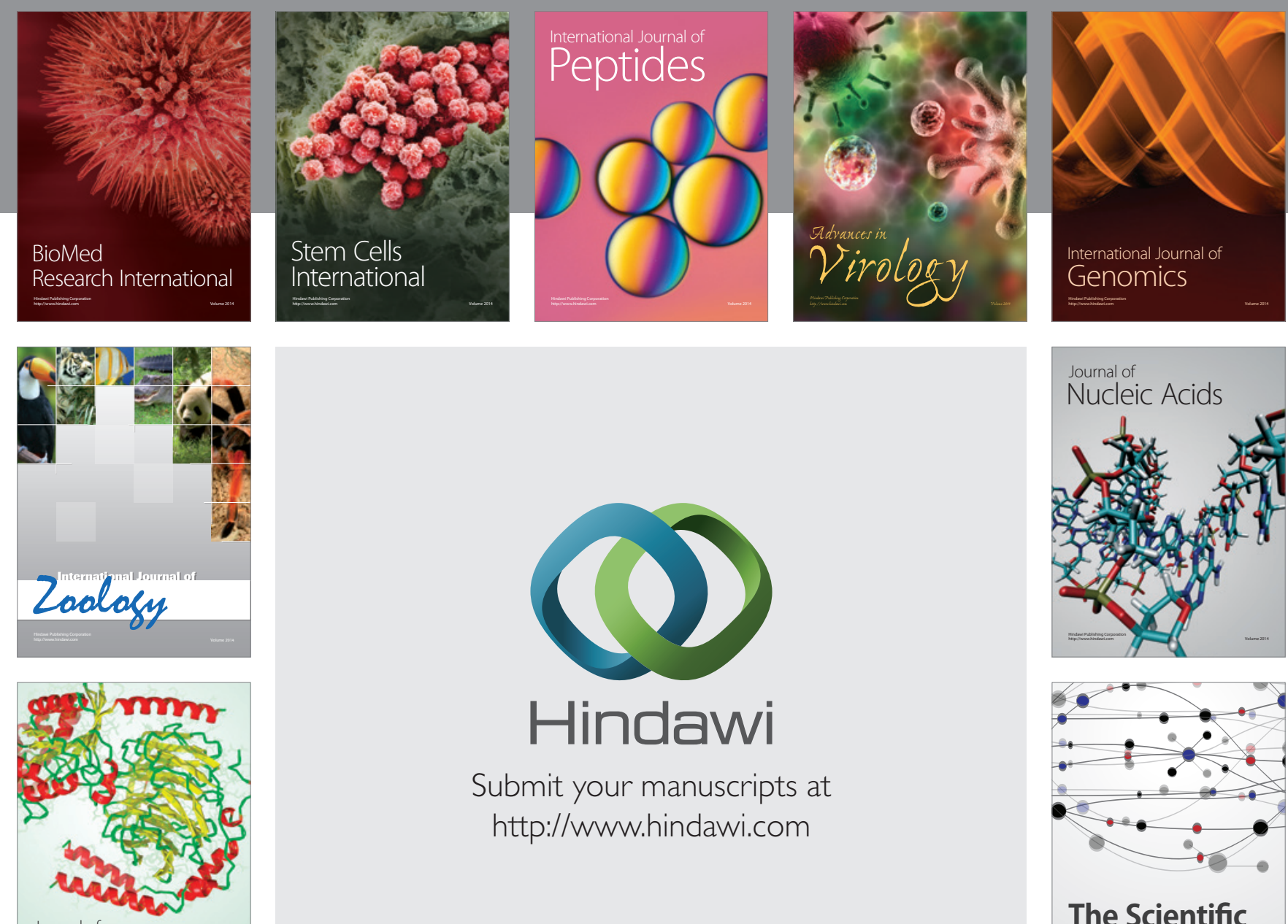

Submit your manuscripts at

http://www.hindawi.com

Journal of
Signal Transduction
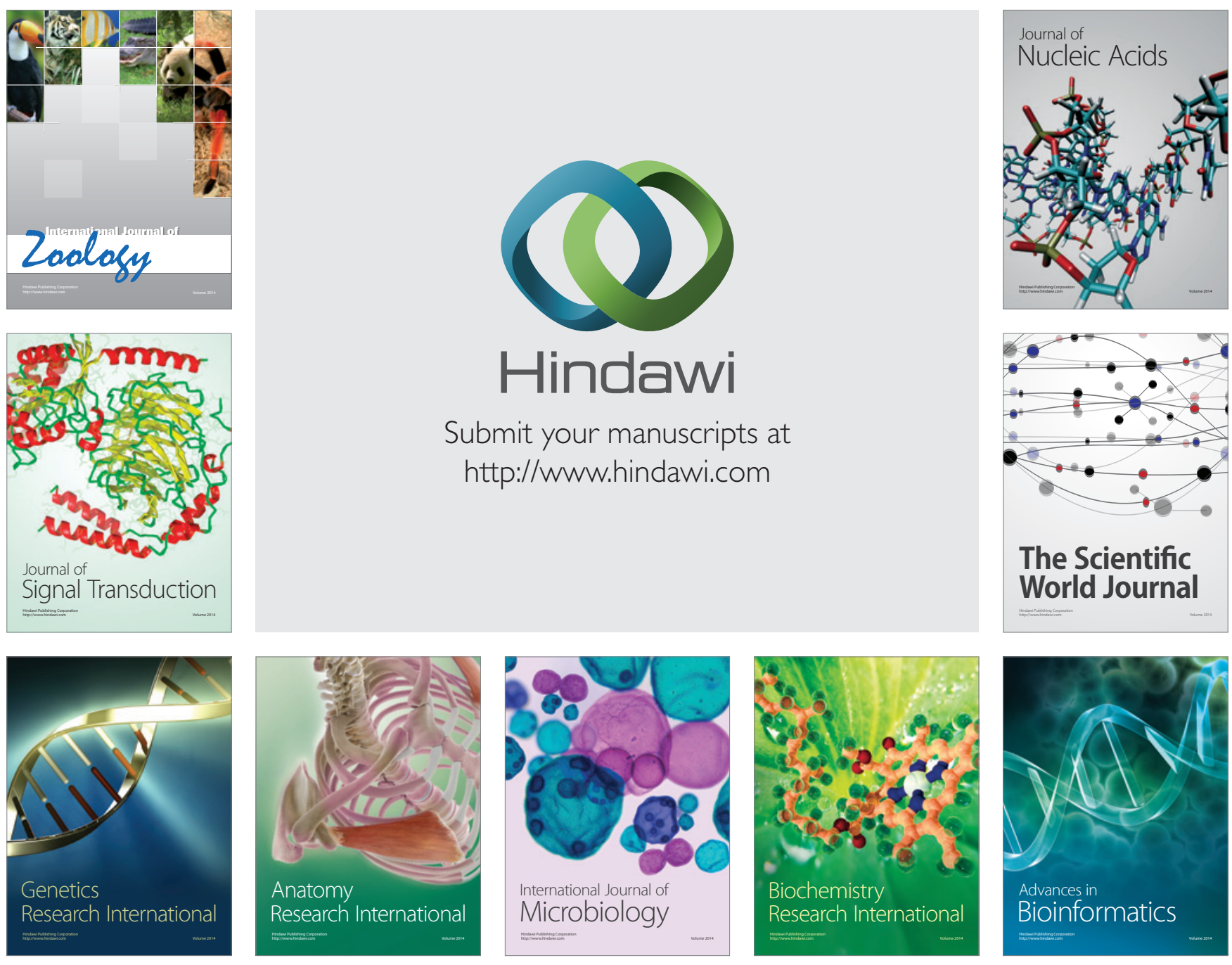

The Scientific World Journal
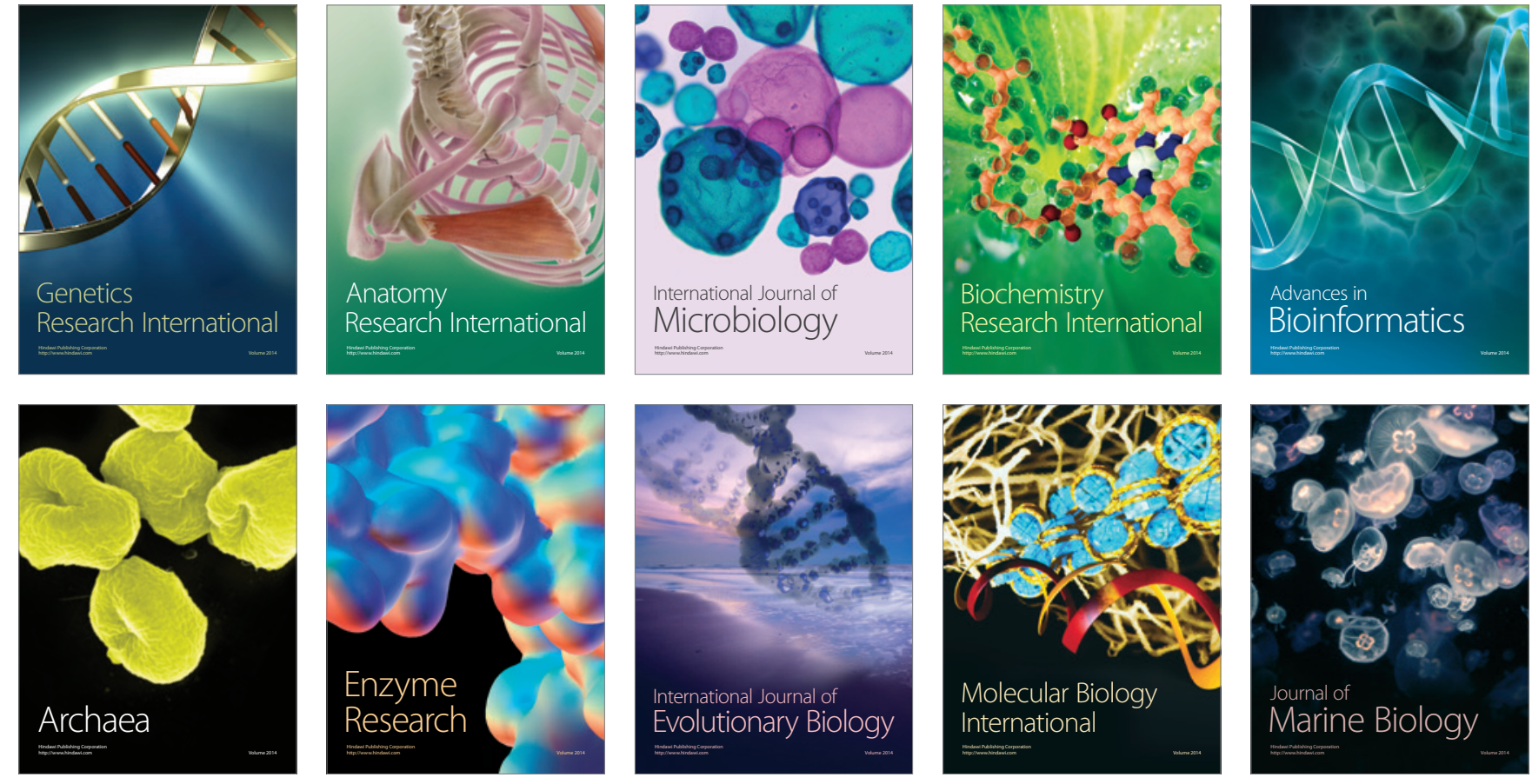